\title{
Brucella Genomics: Macro and Micro Evolution
}

\author{
Marcela Suárez-Esquivel ${ }^{1}\left(\mathbb{D}\right.$, Esteban Chaves-Olarte $^{2}$, Edgardo Moreno $^{1}{ }^{(\mathbb{C})}$ and \\ Caterina Guzmán-Verri 1,2,*(D) \\ 1 Programa de Investigación en Enfermedades Tropicales, Escuela de Medicina Veterinaria, Universidad \\ Nacional, Heredia 3000, Costa Rica; marcela.suarez.esquivel@una.cr (M.S.-E.); \\ edgardo.moreno.robles@una.cr (E.M.) \\ 2 Centro de Investigación en Enfermedades Tropicales, Facultad de Microbiología, Universidad de Costa Rica, \\ San José 1180, Costa Rica; esteban.chaves@ucr.ac.cr \\ * Correspondence: catguz@una.cr
}

Received: 1 September 2020; Accepted: 11 October 2020; Published: 20 October 2020

\begin{abstract}
Brucella organisms are responsible for one of the most widespread bacterial zoonoses, named brucellosis. The disease affects several species of animals, including humans. One of the most intriguing aspects of the brucellae is that the various species show a $\sim 97 \%$ similarity at the genome level. Still, the distinct Brucella species display different host preferences, zoonotic risk, and virulence. After 133 years of research, there are many aspects of the Brucella biology that remain poorly understood, such as host adaptation and virulence mechanisms. A strategy to understand these characteristics focuses on the relationship between the genomic diversity and host preference of the various Brucella species. Pseudogenization, genome reduction, single nucleotide polymorphism variation, number of tandem repeats, and mobile genetic elements are unveiled markers for host adaptation and virulence. Understanding the mechanisms of genome variability in the Brucella genus is relevant to comprehend the emergence of pathogens.
\end{abstract}

Keywords: Brucella; brucellosis; genome reduction; pseudogene; IS711; SNPs

\section{Introduction}

The Proteobacteria phylum represents the most extensive bacteria domain known. This name is derived from the Greek protean, literary meaning "first," and coincidentally to the god Proteus who could change his form. Within this phylum, there is the Alphaproteobacteria Class, encompassing bacteria with different shapes, lifestyles, metabolic capacities, and ecological variation (Figure 1) [1]. From the lifestyle perspective, this Class includes free-living, commensals, endosymbionts, opportunistic, and intracellular pathogenic bacteria [2-4] and therefore is an excellent model for studying the evolution of parasitic bacteria. The genus Brucella belongs to one of the Class families, the Brucellaceae family, which includes the genera Pseudochrobactrum, Falsochrobactrum, Ochrobactrum, and Brucella [5]. The average genome size of Brucella organisms is $3.3 \mathrm{Mb}$, divided into two circular chromosomes of different sizes: $2.1 \mathrm{Mb}$ and $1.2 \mathrm{Mb}$ [6]. There are Brucella organisms with a single megareplicon of $3.3 \mathrm{Mb}$, a consequence of the fusion of the two chromosomes [7]. The Brucella genome is conserved and stable due to traits such as its substantial DNA guanosine $(G)+$ cytosine $(C)$ content $(~ 57 \%$ mol). Besides, there is no evidence of plasmids, horizontal DNA transference, active lysogenic phages [3], or recent external recombination events $[3,8,9]$. These properties, therefore, preclude the acquisition of exogenous genetic material by classical recombination or phage integration. Based on its genomic traits and strict molecular classification, Brucella is considered a monospecific genus. Nevertheless, the taxonomic ranking recognizes several species based on host range preference, phenotypic and genotypic characteristics, and biological behavior [10]. It is also clear that the classical Brucella organisms fit the definition of ecotypes from the biological, biochemical, genomic, and medical perspectives. It is 
intriguing how the various Brucella species/strains, displaying a very close genetic relationship ( $97 \%$ similarity), still exhibit different host preferences [11], virulence [10,12], and zoonotic potential [13].

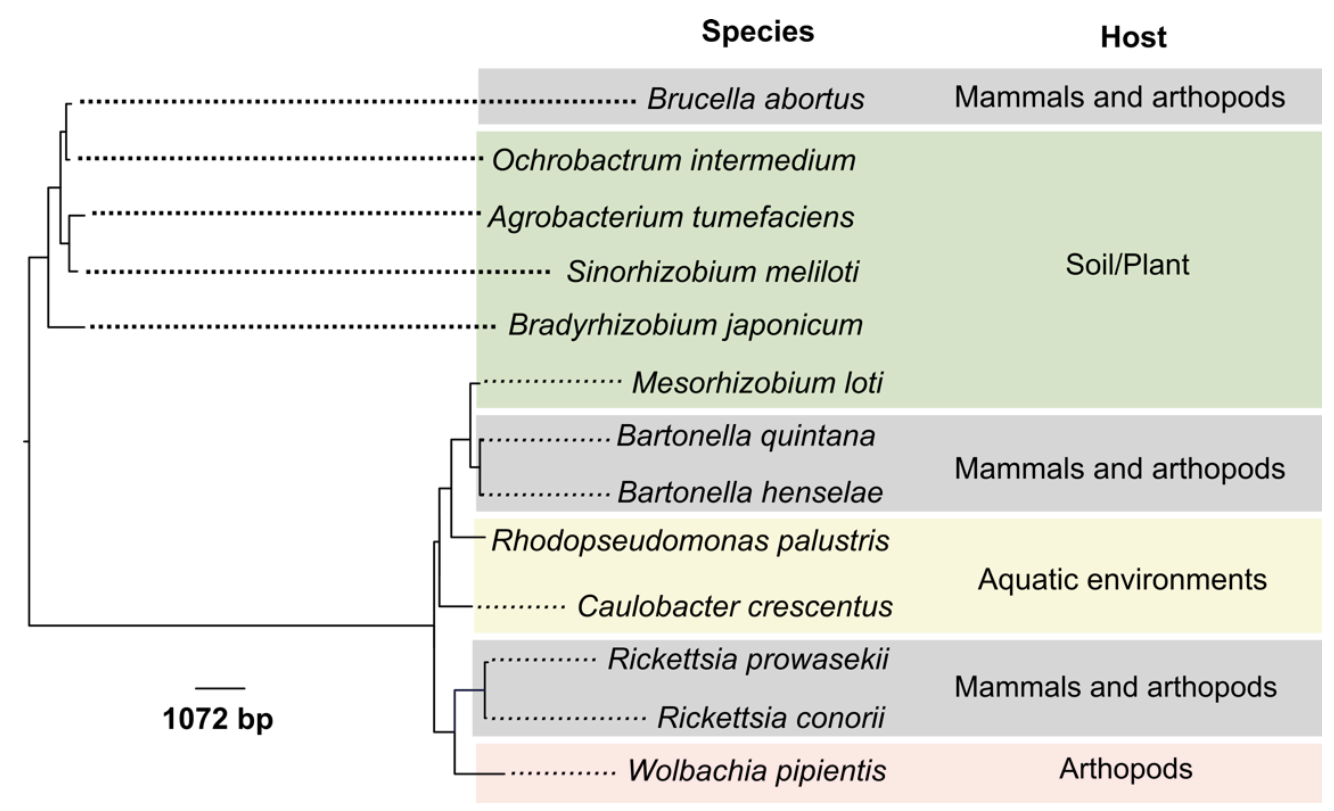

Figure 1. The phylogeny of some representative Alphaproteobacteria inferred by maximum likelihood reconstruction based on the 16S rRNA gene. The sequences used as outgroup [14] were trimmed out from the tree to enhance the resolution. The analysis involved 17 nucleotide sequences; there were a total of 1191 positions in the final dataset. Table S1 indicates the details of the strains and sequences used for the analysis. Ochrobactrum intermedium may behave as opportunistic bacteria in immunocompromised human hosts $[15,16]$.

Information regarding differences in the genomic organization among Brucella species, phylogenetic proximity and the description of two separated chromosomes was obtained during the 1990s, using Pulse-Field Gel Electrophoresis (PFGE) $[6,17,18]$. Multi-locus sequence type (MLST) and multiple loci variable number of tandem repeats (VNTR) analysis (MLVA) are now used to infer genetic diversity in Brucella by sequencing multiple genetic loci. They allow geographic clustering of the isolates, tracking sources of infection and their global dispersion [1-22]. Although the MLST classification has some practical application, sensu stricto a genetic variability is a continuous event that cannot be restricted to types, but rather to phylogenetic relations. Therefore, MLST classification, as well as MLVA classification, have to be taken cautiously. Moreover, the branching and rooting topology of the dendrograms determined by MLVA and MLST do not necessarily coincide with the phylogenetic trees resolved by WGA.

The whole-genome sequence (WGS) analysis based on single nucleotide polymorphisms (SNPs) or core genome is currently the predominant technique to infer the evolutionary history and diversity of several pathogens in different hosts and locations, including Brucella species.

Following the increasing availability of Brucella WGS generated in the last decade and computational power to analyze these sequences [23-27], we have reviewed the variability of genetic traits concerning host preferences and the brucellae geographic origin.

\section{Genome Reduction in Cell-Associated Alphaproteobacteria}

Alphaproteobacteria organisms are found in different environments, including water and soil, and can form extra- and intracellular associations with unicellular and multicellular eukaryotes [28]. Environmental and plant-associated genera such as Caulobacter and Bradyrhizobium, possess large genomes ranging from 4.0 to $9.1 \mathrm{Mb}$, respectively [29,30]. With intermedium genome sizes between 
3.3 and $1.6 \mathrm{Mb}$, there are intracellular-extracellular facultative organisms like Brucella and Bartonella species, which can infect animals and are zoonotic [3,7,31,32]. Taking apart mitochondria, Rickettsia and Wolbachia are the species with the smallest genome sizes of the Class, 1.1-1.3 Mb length, which are obligate intracellular pathogens or symbionts of arthropods and nematodes; some of them are zoonotic [33,34].

Gene loss and bacterial chromosomal streamlining are proposed mechanisms for generating smaller genomes $[3,4,35]$. Loss or reduction of non-essential genes or sequences might occur within the context of changes in the surrounding bacterial environment. In cases, gene reduction delivers the so-called "non-culturable" bacteria, which may be a predictive marker of pathogenicity in bacteria [36]. Examples of gene reduction are the intracellular parasitic bacteria of the order Rickettsiales, with genome size ranging from $2-1.1 \mathrm{Mb}[28,37,38]$. Some of the lost genes in this animal cell-associated bacteria are related to the synthesis of essential metabolites such as amino acids, carbohydrates, and vitamins supplied by the host cell [39]. Wolbachia species and mitochondria are extreme genome reduction cases, in which genome streamlining promoted a permanent stage of endosymbiosis, with a high replication rate within the host environment $[4,35,40,41]$. Likewise, there are reports in gene decay on critical metabolic pathways in Brucella [27,42], and the chromosomal streamlining seems to have been an essential step in the separation from its closest relative, Ochrobactrum [3,43], as further detailed.

\section{Brucella Genome Macroevolution Includes Gene Loss}

The close phylogenetic relationship of Brucella organisms with soil-arthropod-plant-associated bacteria suggests that the common ancestor of Brucella evolved from opportunistic organisms close to 500 million years ago that adapted to an intracellular life probably in a cold-blooded vertebrate [44], later on adapting to mammals $[15,45,46]$. Phylogenetically, the closest bacterial species to the genus Brucella are species of the genus Ochrobactrum, such as Ochrobactrum anthropi and Ochrobactrum intermedium (Figure 1). These are soil bacteria associated with plants that may behave as opportunistic bacteria causing nosocomial infections in immunocompromised human hosts $[16,47]$. Similar to Brucella species, Ochrobactrum organisms have two circular chromosomes. However, the genome size of Ochrobactrum is larger than the brucellae genome and contains several plasmids. The Ochrobactrum anthropi chromosome I contains $\sim 2.9$ million bp with a prototypical bacterial chromosome origin of replication and a chromosome II of $\sim 1.9$ million bp with a repABC origin commonly found in secondary chromosomes of a plasmid origin [48]. Both chromosomes have an average $\mathrm{G}+\mathrm{C}$ content of $\sim 56 \%$ and encode $\sim 4425$ protein-CDS, along with 31 pseudogenes and 73 structural RNAs (rRNA, tRNA, and small RNA). Due to their characteristics, it was proposed that the second smaller chromosome derived from a megaplasmid that acquired housekeeping genes [3]. Still, compared to other phylogenetically related Alphaproteobacteria associated with plants such as Bradyrhizobium or Sinorhizobium species, the genomes of Ochrobactrum organisms have undergone significant reduction, which may be a trait in this lineage [49].

As expected, the two Ochrobactrum sp. chromosomes are similar and display collinearity to the two brucellae chromosomes. Nevertheless, the brucellae genomes are approximately $30 \%$ smaller than those of Ochrobactrum organisms $[3,28,48,50]$. In at least one non-classical Brucella strain named $B$. inopinata $\mathrm{BO} 1$, a temperate-like broad host range phage, which under certain stringent conditions can be expressed, has been described [51]. Since this phage is similar to that found in Ochrobactrum ssp., it might indicate that ancestral brucellae harbor lysogenic phages.

The close interaction during millions of years between Brucella organisms with host cells shaped the bacterial genome [52]. This condition likely imposed bottlenecks in the genes-flow of Brucella, favoring gene reduction and streamlining, including the elimination of accessory genetic elements $[3,53]$. The two main mechanisms of gene reduction and streamlining proposed in prokaryotes include deletion bias and purifying selection [41]. In the first mechanism, the rate of DNA loss is naturally higher than the rate of DNA acquisition [54]. In the second mechanism, DNA sequences are selected against, favoring the selective removal of deleterious alleles that are non-functional, non-essential, or redundant [55]. 
Alternatively, bacteria such as the obligate intracellular Orientia tsutsugamushi, display massive amplification of mobile elements during functional reductive genome evolution [38]. Close to $50 \%$ of the genome contains repetitive sequences derived from an integrative and conjugative element, ten types of transposable elements, and seven short repeats of unknown origins. The amplification and degradation of these sequences resulted in intensive genome shuffling and produced many repeated genes, most of them pseudogenes.

Genome reduction can also stabilize selection through the purging of deleterious genetic polymorphisms that arise through random mutations. Deletion bias seems to be the mechanism responsible for restricting genome diversity and particularly relevant in those "clonal" prokaryotes in which recombination events are precluded, such as members of the genus Brucella [2]. Despite this, the genetic elements necessary for adapting to a parasitic way of life were retained and modified by internal genetic processes, such as mutation, inversion, translocation, and insertion/deletion of transposable elements, selected within the boundaries to the new restricted host cell environments. For instance, several orthologous structural scaffolds such as the VirB type IV secretion system, the lipopolysaccharide, cell envelope molecules, and various metabolic alternatives required for virulence and intracellular life were first acquired and then remodeled in the Brucella ancestor. For some of those, such as VirB, it has been also proposed that components of the system were horizontally transferred from different sources and times during Brucella evolution and virulence development $[43,56]$. Concomitantly to this event, a stealthy strategy for avoiding the host immune response was developed [57].

The acquisition of characteristics through gene rearrangement, duplication, mutation, and reorganization of mobile chromosomal elements such as insertion sequences (IS) within specific contexts, may have provided the genetic framework for establishing some of the Brucella intra-species diversity [58]. The ancestral acquisition of genes coding for proteins functioning in metabolism, degradation, biosynthesis, and metal transport clustered in genomic regions, called genomic islands (GIs), and shared anomalous regions (SARs); some of them are Brucella species-specific [59,60]. Others, such as genes coding for the O chain of lipopolysaccharide (LPS), functional flagella, phage truncated sequences, pili-like structures, and some broader metabolic alternatives (most of them non-essential for survival), vary between the so-called classical and non-classical Brucella groups [61] clustered in two phylogenetic groups (Figure 2) [62]. Still, other genes are orthologues to plant-associated Alphaprotebacteria but absent in Ochrobactrum species, suggesting that some of these islands and anomalous regions may have been present in the Ochrobactrum/Brucella ancestor but lost during the emergence of the Ochrobactrum lineage [43]. As stated, Ochrobactrum has also lost genes and reduced its genome in comparison to other Alphaproteobacteria close soil/plant relatives, such as Agrobacterium and Sinorhizobium organisms with larger genomes [49].

\section{Expanding the Number of Brucella Species}

Based on WGS, the Brucella genus may be divided into two distinct phylogenetic clusters [62]: those that display $>99 \%$ DNA similarity as compared to the B. melitensis $16 \mathrm{M}$ reference genome and therefore recognized as the "classical" species, and those displaying a DNA similarity close to $\sim 97 \%$, recognized as the "non-classical" Brucella species (Figure 2). While the former cluster is a homogenous group limited to mammals, the latter group is continuously increasing its members and includes more diverse brucellae strains found in various vertebrates, including mammals, Anura, fish, and chameleons [44,61-66]. The "non-classical"" Brucella species found in amphibians and fish exhibit high genetic flexibility are motile, fast growers, and more resistant to high acidity and unfavorable environmental conditions [61,67].

Notwithstanding the increasing availability of hundreds of Brucella WGS, they still seem insufficient to reveal the basis of their host restriction and differential virulence [23]. For example, among the classical brucellae, the closer phylogenetic relative of $B$. canis is $B$. suis biovar 4, with only 253 SNPs differences [68], and of B. abortus is B. melitensis, separated by 2400 SNPs. However, these bacteria 
display distinct host preferences and virulence [69]. Moreover, B. cet $i$ is an aggressive pathogen for cetaceans, while B. pinnipedialis is a mild pathogen for seals and walruses [70-72]. For comparison, Salmonella enterica serovars responsible for gastrointestinal and systemic disease [73] often have a broad host range, like S. enterica serovar Enteritidis [74]. However, serovars Paratyphi A and Typhi are restricted to humans, while serovar Gallinarum is a pathogen of chickens [73-75]. When compared, 4810 SNPs separate the genomes of serovar Paratyphi A isolates [76], and the genomes sizes of Paratyphi and Typhi differ by $14.5 \mathrm{~kb}$. Nevertheless, they share the same host preference [74,75]. The genome size difference when comparing the serovar Gallinarum to Typhi is $150.3 \mathrm{~kb}$, being the former smaller [74].

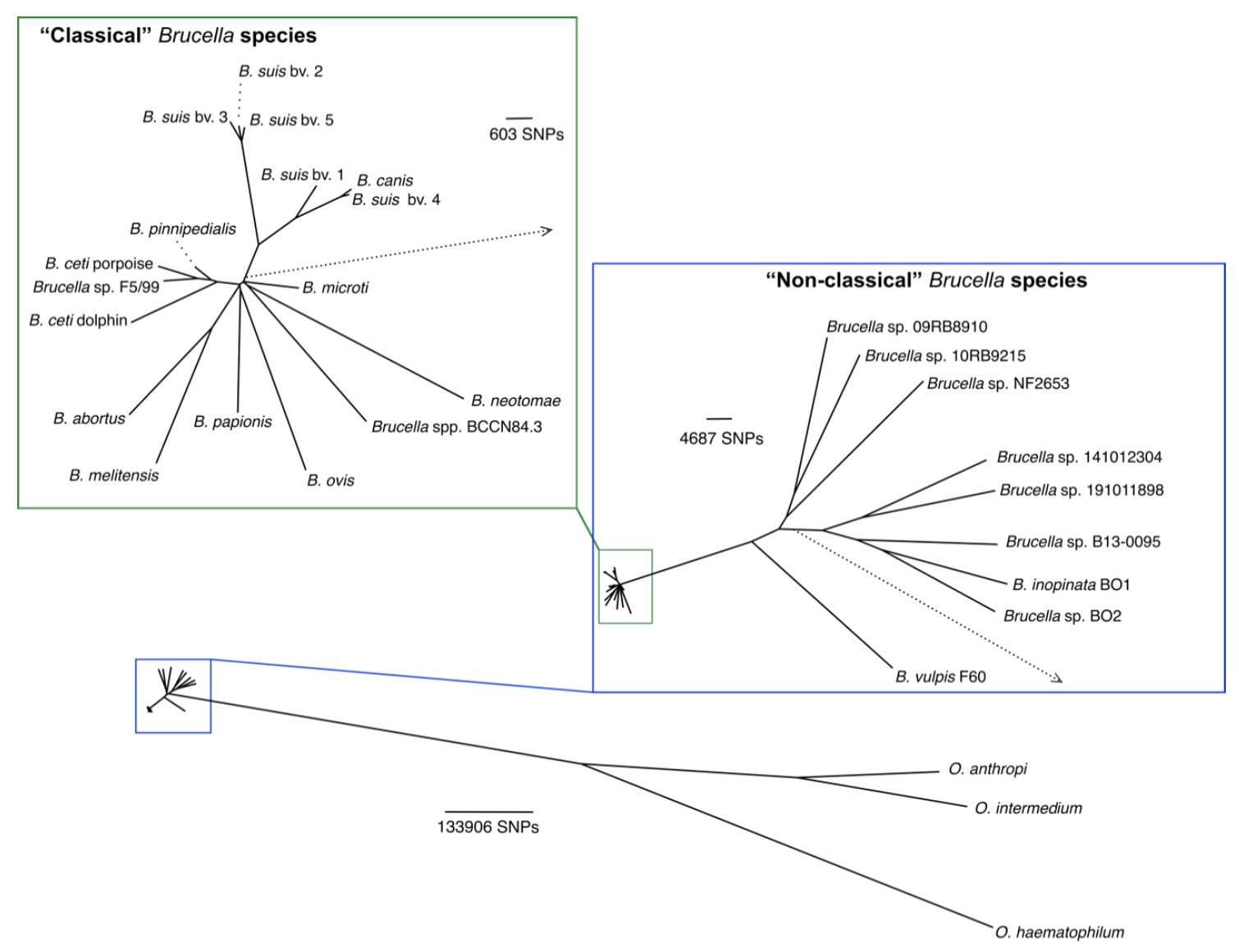

Figure 2. Phylogenetic relationship of "classical" and "non-classical" Brucella species and Ochrobactrum sp. based on 669529 SNPs. Segments of the tree were magnified to increase resolution. The SNPs scale is next to each magnified region. The dotted arrow represents the branch linking the magnified regions to the whole tree. A blue square highlights all Brucella species; the "classical" species are within the up left square. Modified from [77]. In Table S1 are the details of the strains and sequences used for the analysis.

The similitude among the various classical Brucella species represents a clinical diagnostic problem since the traditional bacteriological and molecular identification methods lack resolution power $[58,69]$. For this reason, many Brucella isolates recovered from various animal species had been misclassified. One relevant example is depicted by the discovery of $B$. neotomae, a parasite of wood rats, as a zoonotic agent of two cases of human brucellosis [78,79]. Initially, this bacterium was misclassified as $B$. abortus by classical bacteriological methods. The correct identification of this species was only possible by detailed phenotypic and genotypic analysis, including WGS [78]. After these reports, investigators confirmed the infective potential of $B$. neotomae in mice [80,81]. Another example of misidentification was the Brucella sp. BCCN84.3 isolated from the testes of a Saint Bernard dog with 
orchiepididymitis. This strain displayed distinctive biochemical properties and a unique SDS-PAGE protein profile [82]. This isolate was initially identified under experts' hands as B. melitensis biovar 2, afterward as an atypical B. suis [77]. MLVA-16, WGS, and detailed phenotypic characterization identified the Brucella sp. BCCN84.3 as distinct species, after 35 years of its isolation [77]. Due to their broader metabolic alternatives, non-classical Brucella isolates from humans were initially identified as Ochrobactrum spp. [83]. Likewise, Brucella isolates from a dwarf sperm whale (Kogia sima) were not successfully identified by biochemical profiles or traditional molecular typing techniques, such as Bruce-ladder PCR [84]. Still, both MLVA-16 and WGS based phylogenetic reconstruction clustered this strain with isolates of the sequence type (ST) 27, a genotype that had been previously associated with infection in humans [85]. Similar to these cases, Brucella isolates from rodents in Queensland, Australia, that displayed particular biochemical properties were considered atypical B. suis biovar 3 and kept frozen since 1965 [86,87]; only after the genomic era, the phylogenetic analysis revealed their close relationship with the non-classical $\mathrm{BO} 1 / \mathrm{BO} 2$ clade, representing a distinct lineage [88].

\section{Brucella Speciation Bottleneck Through the Domestication of the Preferred Host}

Domestication has promoted inheritable phenotypic and behavioral changes in originally wild animals. These changes are linked to modifications in the genetic flow of domesticated populations, mainly as a consequence of selection for anthropogenic purposes such as (i) maximization of the number of productive offspring obtained by breeding; (ii) maximization of the efficiency of food conversion of animal products and working force, (iii) minimization of energy expenditure and losses induced by infectious, metabolic diseases, and stress [89-91]. The geographic and social environment, the size of the herds, the type of reproduction strategy, the proximity to wildlife, the quality of food, transport, human taste, and possibly vaccines that do not prevent transmission are selective factors for specific genes [91-93].

In asexual bacterial populations with limited genetic variation, epigenetic plasticity may be a significant source of variation, enabling fast adaptation to new environments, which is then fixed through regular genetic modifications. However, domestication is not unidirectional, and both the microbiome and pathobiome are selected during this process that works as a "bottleneck," reducing the genetic diversity commonly found in wildlife populations [94]. In the case of Brucella organisms, we can assume that it is not a random event that the most virulent Brucella species, with the broader host range, are those that preferentially infect domestic animals [12] (Figure 3). This event is not a rare phenomenon. After domestication, bacterial pathogens may be selected and jump back and forth between bovids and humans during the early Holocene [95]. This hypothesis is commensurate with the less zoonotic potential of Brucella species isolated from wild animals, such as dolphins, walrus, or voles [12]. These observations may still be biased since comparisons between Brucella isolates from wildlife and domestic animals are lacking. One important exception is B. ovis. This bacterium is non-zoonotic and displays a strong host preference for rams, a phenomenon that demonstrates adaptation towards its host accompanied by a significant genome degradation as compared to other Brucella species [12,52,96,97]. 


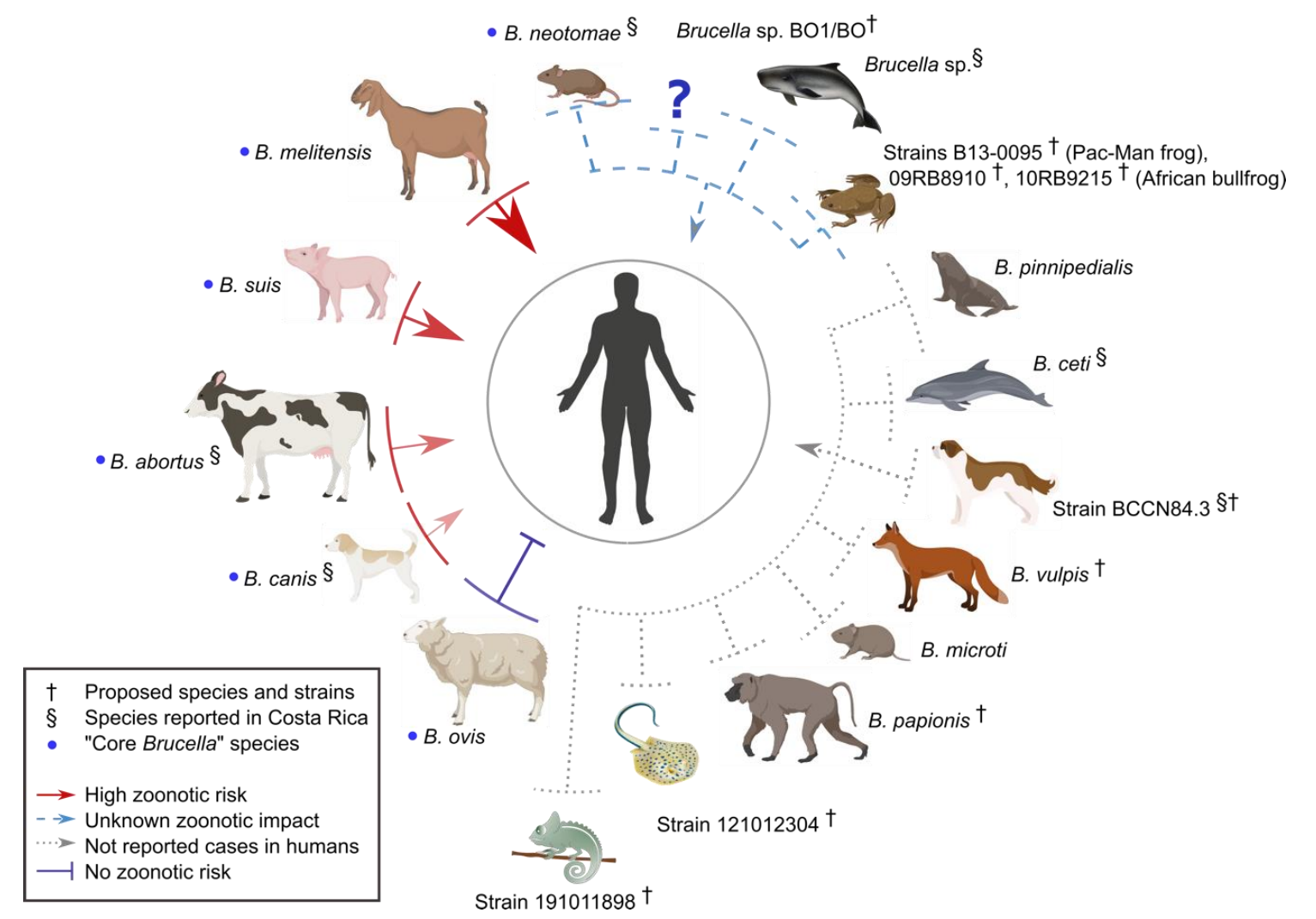

Figure 3. Zoonotic potential of the various Brucella species. The colors and arrow sizes represent the zoonotic risk displayed by each species isolated from its preferred host. Table S2 presents a detailed analysis. Created with Biorender.com.

\section{Brucella Host Distribution from Different Geographic Areas}

Despite the high genetic similarity among the various Brucella species, DNA analyses have shown clustering patterns consistent with the geographic origin of the preferred host $[20,21,27,98]$. This clustering is appreciated in brucellae isolates from marine mammals (e.g., B. ceti and B. pinnipedialis), as shown by MLST, MLVA, and WGS. The identified genotypes follow strong correspondence with their host geographic origin [27,98-101]. WGS SNPs phylogenetic reconstruction supported and extended the topology resolved by MLVA-16. The MLVA-16 "A2" and "B" clusters, however, appeared as part of a single genomic lineage, a picture that may change when more genomes are available for analysis. Likewise, the MLST schemes divided B. cet $i$ into two main sequence types (ST): the ST23 complex and ST26 complexes. These two STs have porpoises and dolphins as preferred hosts, respectively. $B$. pinnipedialis ST53 and ST54 infect preferentially hooded seals, while ST24, 25, 51 and 52, infect other pinnipeds [21,99,102].

Additional to the genotypic clustering pattern seen in B. ceti and B. pinnipedialis, specific phylogeographic signatures have been described [27], meaning "genomic elements that show a segregation pattern that is consistent with geographic distributions of individuals" [103], constituted by differential pseudogenes, number and position of IS711, and by reordering and inversion of GIs and SARs.

In B. suis, there is a tight congruency between genotype and biovar designation [21], which differs according to geographic distribution and host range [22]. B. suis biovars 1 and 3 are zoonotic, and the preferred hosts are domestic pigs and occasionally wild boar [104,105]. The B. suis biovar 1 is common in South America and Asia [106-108], while biovar 1 and biovar 3 are mainly present in the United States, Australia, and China [109-112]. B. suis biovar 2, mainly restricted to hares and wild boars in Euroasia, also infects domestic pigs [22,113], but rarely humans [114]. B. suis biovar 4 is a pathogen of 
reindeer and caribou and a zoonotic risk in the Arctic region $[105,115]$. B. suis biovar 5 from Eastern European rodents seems confined to their natural hosts and is seldom found in domestic animals or humans $[69,105,116]$.

Similar to the biovar distribution, two genetically divergent major B. suis clades were described by MLVA, MLST, and WGS phylogenetic reconstruction: one included B. suis biovar 2 and the second one $B$. suis biovars 1,3 , and 4 and B. canis. B. suis biovar 5 forms a separated branch $[21,98]$.

According to MLST, the B. abortus isolates globally comprise three major clades: A, B, and C. The A and $B$ clades include isolates from Africa and consist predominantly of biovar 1, 3, and 6 . In contrast to the geographical restriction of clades $A$ and $B$, isolates of clade $C$ have a global distribution [21]. The WGS analysis supported this continental segregation [117]. However, comparisons of different bacteria from smaller geographic areas by WGS and MLVA are not always straightforward, as it will be further discussed [26,117-120].

\section{Brucella Speciation and Host Preference: Small Genetic Differences Matter}

When comparing Brucella genomes, it is essential to consider that most of their variability is found in $\sim 3 \%$ of their content. Strains or isolates from the same outbreak or within the same host show less variation among them. This characteristic may be trivial compared to other Gram-negative bacteria such as E. coli and S. enterica. Indeed, isolates of S. enterica serovar Typhimurium can vary from $2 \%$ to $20 \%$ only in genome size; also E. coli O157:H7 has a 20\% larger genome than E. coli K-12 [11,121]. The variation found within those genera far exceeds the Brucella genomic diversity [11]. However, it is remarkable that despite this homogeneity, the Brucella species display different phenotypic characteristics, host preference, virulence, and zoonotic risk. Some elements that might account for genome variability are related to (i) VNTR, (ii) differential SNPs positional patterns, (iii) an increased number of pseudogenes as compared to the most common recent ancestor, (iv) number and distribution of mobile genetic elements (e.g., insertion sequences), and (v) number and distribution of GI and SARs $[11,20,27]$. Although there is no investigation of the epigenetic modification sites in Brucella organisms, the CcrM methylase that recognizes the double-stranded sequence GANTC may induce the methylation on both strands and therefore be a source of epigenetic modifications $[122,123]$.

\subsection{Variable Number of Tandem Repeats}

DNA tandem repeats (TRs), also called satellite DNA, are inter- or intragenic nucleotide sequences repeated two or more times in a head-to-tail manner. Loci that include TRs are hypermutable because tandem tracts are prone to strand-slippage replication and recombination events that cause the TRs copy number to increase or decrease [124,125]. The evolutionary clock speed at each locus is variable, and differences in the TR copy number at multiple loci have proven useful for gathering epidemiological information as well as characterization of intra- and inter-population variation [126,127]. Furthermore, rearrangements of intergenic TRs can confer transcriptional evolvability and phenotypic variation $[124,125]$.

The first application of VNTRs for Brucella genotyping used microsatellite fingerprinting based on the number of TRs of the sequence "AGGGCAGT" at eight loci in the genome. The technique was called "HOOF-Prints" as an acronym for Hypervariable Octameric Oligonucleotide Finger-Prints [128]. Afterward, Le Flèche et al. [20] and Whatmore et al. [19] applied this method into a phylogenetic context. Le Flèche et al. [20] expanded the TRs to 15 different loci, named MLVA-15, divided into two panels: panel 1, composed of eight "user-friendly" minisatellite markers with good species identification capability, and panel 2, a complementary group of seven markers with higher discriminatory power [20]. Subsequently, the original eight HOOF-Prints were used altogether with an additional eight short 5$8 \mathrm{bp}$ TRs, to reduce the risk of a match due to homoplasy and included in an MLVA-16 scheme [20]. Whatmore et al. [19] implemented a larger scheme based on 21 different loci aiming to increase the resolution of the technique. 
The use of MLVA has proved useful for tracking Brucella outbreaks or infection sources to study the molecular epidemiology of Brucella in specific countries [129-132] and in a worldwide context [98]. Despite its usefulness, the homoplasy in VNTR markers in some Brucella species, as B. abortus and B. ovis, lowers the levels of discrimination and resolution of cladograms as compared to WGS phylogenetic analysis $[26,117,120]$. To reduce homoplasy and to understand phylogenetic relationships deeper, a systematic approach in Brucella MLVA, is to use the most stable VNTRs or provide further weight to the markers [133]. However, this could limit the evidence of more recent epidemiological connections [134]. Species like B. melitensis and B. ceti have proven a fair comparison of MLVA-16 cladograms and WGS phylogenetic reconstruction in the global context $[27,135]$. Nevertheless, MLVA-16 lacks resolution in comparative studies between B. melitensis and B. abortus, and inferring phylogenetic distances, clusters or groups within the same location is not as straightforward as in WGS-based approaches $[26,136]$.

\subsection{SNPs Barcode Patterns and Allelic Variation}

SNPs have simple variation patterns, low mutation rates, and low levels of homoplasy [137]. Halling et al. [138] used SNPs analysis for the first time in Brucella to compare the three available genomes at the moment: B. abortus st. 9-941, B. melitensis st. 16M and B. suis st. 1330. They found an average of one SNP per 463 nucleotides $[65,138]$. SNPs positions across Brucella genomes relative to phylogenetic reconstruction can be interpreted as distinctive barcode patterns, including not only information regarding the SNP itself but also its positional context in the genome. Some specific SNPs clusters resembling barcodes or fingerprints were identified in Brucella genotypes from terrestrial and marine mammals [27]. This differential pattern may be relevant since SNP variations could influence the expression of neighbor coding sequences (CDS) or RNA coding genes, contributing to niche adaptation $[103,139]$.

On the other hand, one SNP could be the cause of host adaptation and increased virulence as described for other bacteria, despite being located in intergenic regions $[140,141]$. Isolates of $B$. abortus collected during a time-span of three years and from a very restricted geographical area of $18.75 \mathrm{Km}^{2}$ showed 1-18 SNPs that allowed phylogenetic sub-clustering [117]. B. melitensis isolates from a restricted geographical area in South-East France from three different hosts displayed a single SNP difference [142].

MLST schemes are valuable tools to investigate genetic relationships within species of the Brucella genus [8,21]. The MLST method uses alleles as the unit of comparison, rather than nucleotide sequences; in this sense, each allelic change is counted as a single event, regardless of the number of nucleotide polymorphisms involved. Each locus is part of a profile or an ST designated by a number [143]. The corresponding ST may be associated with biological properties, such as virulence or host preference [144]. The first MLST profile for Brucella was developed in 2007 and included nine distinct genomic fragments, seven representing classic housekeeping genes known as gap, aro $A, g l k$, $d n a K, g y r B, \operatorname{trpE}$, and $c o b Q$. The two remaining loci were variable markers: a fragment of the omp25, encoding a $25 \mathrm{kDa}$ outer membrane protein, and int-hyp region, which included an intergenic segment and, partially, a hypothetical protein [8]. As the technique developed and the Brucella genus expanded, further variation was obtained, and the original protocol improved the resolution and discriminatory power. After that, the 9-loci scheme incorporated 21 loci, including multiple alleles for loci [21].

The current MLST profiles have shown diverse genotypes among samples of the same species, unveiling variability related to geographic origins, phenotypic biovars profile [21], pathogenic potential, and host restriction [99]. As stated before, although in some cases the MLST classification seems a practical taxonomical tool, the genomic variability should not be restricted to types, but rather to phylogenetic relations; therefore, conclusions regarding the dispersion and evolution of Brucella should be based on ancestor/descendant relationships and not on MLST. 


\subsection{Pseudogenes}

The importance of pseudogenes in bacterial diversification and evolution is just recently being unveiled. There seems to be a consensus within the scientific community on the functional definition of what is a pseudogene. At the same time, there are different criteria related to which are mechanisms of pseudogenization and how they are inferred from automated annotation pipelines, or manually annotated [145]. This is not trivial, since conclusions based on pseudogene analysis might differ from one study to another, simply because the criteria for pseudogene annotation are different. From the functional point of view, pseudogenes are "fossil" sequences, which may serve as "genetic reservoirs" for plasticity, required for evolution $[145,146]$. In other cases, they are genes with a new function, since they participate in gene regulation and RNA interference (RNAi) roles $[147,148]$. From the mechanistic point of view, bacteria pseudogenes are defined here as any gene containing deletions, insertions, or both, which remove start or stop codons, or at least one in-frame stop codon that may or may not involve frameshifts compared with orthologs, possessing coding or regulatory fragment sequences. Some of the most common mechanisms found after manual curation of eight Brucella genomes are depicted in Figure 4 and Table S3. Analysis of Brucella genome degradation has been studied previously, using different pseudogene definitions and methods for data extraction [42,53,138]. Brucella species show a variable number of pseudogenes, and most of them are in the smaller chromosome $[27,42,96]$. This event is not unexpected, since the smaller Brucella chromosome is generically known as "chromid" probably derived from a megaplasmid possessing a significant number of dispensable non-essential genes than the larger chromosome, which retains most of the housekeeping genes [3].

\section{A. Premature stop codon}

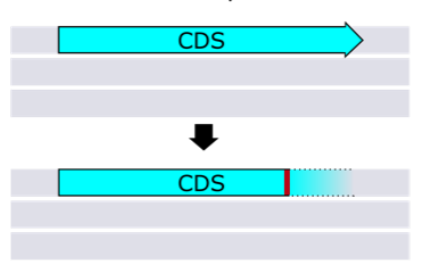

B. Abscense of start codon

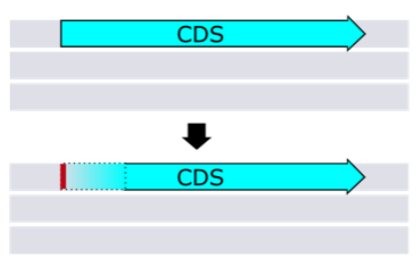

C. Loss of promoter or RBS

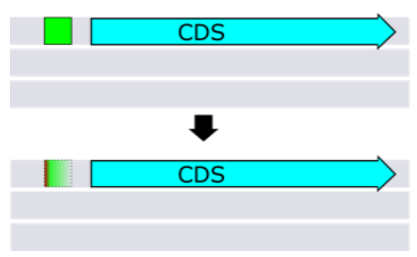

D. Functional domain change

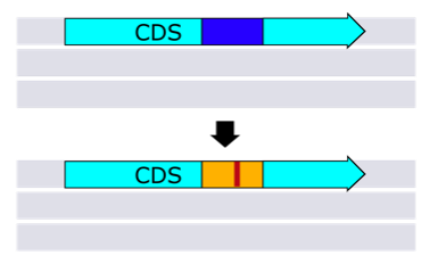

E. Frame shift or frame shift + partial deletion

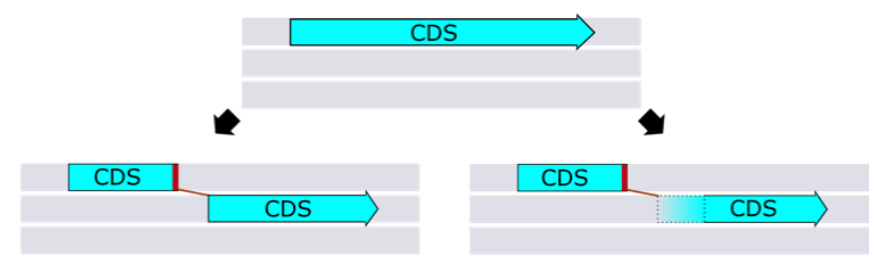

F. Insertion or frame shift + insertion

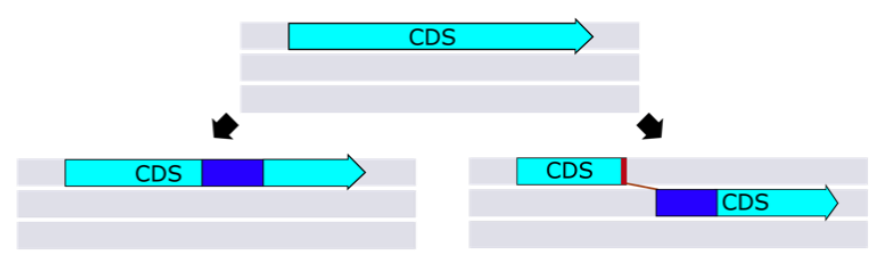

Figure 4. Pseudogenization mechanisms. Schematic representation of pseudogenes induction found in Brucella after manual curation of genome data (Table S3). (A-C) show pseudogenization induced by polymorphisms that change the length of the CDs by the acquisition of a premature stop codon (A), loss of the start codon (B), or alteration of gene expression by promoter loss or regulatory binding sites (C). Polymorphisms also can induce a functional domain change (D) that results in a different product or frameshift (E). Deletions and insertions, shown in $(\mathbf{E}, \mathbf{F})$, can also induce frameshifts. 
Although B. ovis, the species with the largest number of pseudogenes, is not a zoonotic species, it is a relevant pathogen for rams and highly specific for its host [42]. After B. ovis, B. ceti is the second species with a higher number of pseudogenes (Table S3). The number of pseudogenes in B. ceti and B. ovis also supports the idea that members of the genus Brucella have undergone genome reduction according to the "domino effect," in which pseudogenization of one gene may induce the failure of linked functions and the concomitant loss or deletion of more genes by genetic drift $[67,146,149]$. As previously stated, B. ceti also shows a strong host preference.

Phylogenetic analysis from whole-genome sequences of Brucella isolated from marine mammals shows that they represent a branch separated from isolates obtained from terrestrial animals (Figure 2 and [27]). Analysis of the extent of gene degradation at nodes of a phylogenetic tree allowed the finding of putative primary events targeting specific metabolic pathways that have become fixed in this population. The isolates from marine mammals diverging from those isolates of terrestrial animals have lost functions related to energy metabolism, amino acid transport, metabolism, and gene regulation. Extensive pseudogenization in pathways related to fatty acid metabolism, in particular, loss of function of an acetyl-CoA acyltransferase and an acetyl-CoA C acetyltransferase, very likely impairs fatty acids synthesis and beta-oxidation in these isolates. There was further genome degradation in the B. ceti strains from the Pacific, Mediterranean, and Atlantic dolphins. In marine brucellae, amino acid catabolism and pyruvate fermentation seem irrelevant for survival. The genome decay pattern suggests that the loss of function is not a stochastic event but may follow a bottleneck selection by the cell host environment, favoring adaptation and, in course, the generation of ecospecies in marine mammals [27,99]. These properties also seem present in some of the Anura Brucella strains [150].

In course, this loss of metabolic pathways and functions no longer required may promote the facultative or obligate parasitic bacterial stage, suggesting that pseudogenization may narrow the host range and vice versa.

\subsection{Genetic Mobile Elements}

The IS transposition can induce gene inactivation, constitutive expression, or repression of adjacent genes, by reordering IS promoters or terminator sequences. They can also promote the inversion, deletion, duplication, and fusion of replicons if multiple copies of an identical ISs spread over the genome [151,152]. Three main ISs or GMEs described in Brucella are the IS711, Tn2020, and Tn1953 [153,154]. The IS711 described initially in B. ovis has an 842 bp length, a G + C content similar to the rest of the Brucella genome and is delimited by $20 \mathrm{bp}$ imperfect inverted repeats [153]. The Tn2020, of 6002 bp length, was discovered in B. abortus and codes three polypeptides with apparent molecular masses of $71 \mathrm{kDa}, 22 \mathrm{kDa}$, and $14 \mathrm{kDa}$ [154]. The Tn1953, an 18kbp region discovered in the second chromosome of $B$. suis 1330, shows similarity with the anomalous region IncP. The Tn1953 is also present in B. canis, B. neotomae, B. ceti, and B. pinnipedialis, but absent in B. melitensis, B. abortus, and B. ovis [155]. Among these IS, only IS711 is considered a specific element of the Brucella genus and appears to be the only active transposable element in Brucella $[155,156]$. The number and positions of IS711 in the Brucella genomes (Table 1) serve as a fingerprint for diagnosis and species identification [157-160]. The transposition of IS711 has occurred several times in B. abortus, B. ovis, and B. pinnipedialis genomes $[156,160]$. This genetic element plays a role in genome degradation and host adaptation, and it is commensurate with the host geographic distribution [27,42]. 
Table 1. IS711 number according to "classical Brucella" species.

\begin{tabular}{ccc}
\hline Species & Copy Number & Reference \\
\hline B. abortus & 6 complete, 1 truncated & {$[138]$} \\
B. ceti & $>20$ complete & {$[27,161,162]$} \\
B. melitensis & 7 complete & {$[156]$} \\
B. ovis & 38 complete & {$[42]$} \\
B. pinnipedialis & $>20$ complete & {$[161,162]$} \\
B. suis & 7 complete & {$[156]$} \\
\hline
\end{tabular}

In B. abortus, the IS711 induces variation at the strain level as demonstrated by three major deletions in the genomes of three different bacterial stocks of the same B. abortus strain kept in different laboratories: (i) 2308 (NC_007618 and NC_007624), (ii) 2308A (GCA_000182625.1), and (iii) 2308 Wisconsin (ERS568782). The deleted sequences are enclosed by repetitive elements and by IS711 [163]. This event could have induced the loss of regions in 2308 and 2308A as compared to 2308W. Therefore, the conventional concept of strain definition needs to be revised, since variation can be found even among Brucella reference strains. Recently, an intact prophage induced by mitomycin has been identified in B. innopinata, named BiPBO1, of 46,877 bp length and coding eighty-seven putative gene products. Although this prophage was present in B. melitensis and B. abortus, its expression could not be induced by the same method, followed by $B$. innopinata [51]. This characteristic suggests a stage of pseudolysogeny [164] since it is likely that several Brucella organisms do not encode all proteins required for the assembly of intact particles [51]. Since this prophage is also present in Ochrobactrum, it seems ancestral in the several Alphaproteobacteria [51]. The prophage could be expressed in "non-classical" brucellae but not in the classical strains, a fact that corresponds with the closer phylogenetic relation of the former group with Ochrobactrum [51].

\subsection{Genomic Islands and Anomalous Regions Modifications and Distribution}

The GIs is a term that usually refers to DNA sequences acquired during evolution, and so, they display some differences (e.g., $G+C$ content) with the core backbone genome composition. The GIs may be considered as MGEs because they show genetic instability and nearby frequently have repetitive elements, mobility genes (transposases, integrases), and tRNA genes [165-167]. SARs share anomalous regions that contain syntenic protein-coding genes in different Brucella genomes as given by the OrthoMCL ortholog data and double-checked by BLAST2seq [96]. There are 24 GIs and SARs described in the Brucella genus (Table S4, [27]). Some of them are shared among various species, while others are species-specific. Ochrobactrum genes encoded in the GIs suggest that the horizontal acquisition occurred at the Brucella/Ochrobactrum ancestor and lost in the emergence of Ochrobactrum [43], but kept in Brucella. Brucella GIs IncP, GI-1, GI-2, GI-3, SAR1-2, and SAR1-5 include a full-length int gene. Some of the int genes are similar to those that belong to the tyrosine recombinase superfamily (encoded in SAR1-5). Other genes show characteristics similar to those of P4-phage integrases that mediate the excision and transfer or both, of GIs (encoded in IncP and GI-3). These genes, and likely other accessory proteins, mediate GIs excision and rearrangement [60].

There are variations in the position and orientation of genes included in the GIs as revealed by $B$. ceti and B. abortus genome comparisons $[27,117]$. The GIs and SARs were consistent with each one of the species, without significant deletions or insertions. However, there is a particular reordering pattern within the isolates of the same species $[27,117]$. This result is relevant since different positions of the chromosome regions can be associated with different expression patterns [167]. Environmental stimuli can affect the expression level of int, and then mediate the GIs excision and reordering phenomenon. The Brucella GIs instability suggests that these genomic elements are still undergoing an integrative process and raise questions about their role in host specificity, phenotypic differentiation, and virulence $[27,60]$. 


\section{Microevolution of Brucella in the Hosts}

Bacterial microevolution may rise in "clonal" infections, like tuberculosis or brucellosis. This event may occur when variants are detected within a single host or in related hosts during a single outbreak [168]. Studies in Brucella have reported variation of SNPs among isolates recovered from the same host tissues or among isolates obtained from the same host sampled at different times. A study of a B. canis outbreak in Hungary reported variation in five of 15 different VNTR alleles at multiple tissues and dates, during three months, suggesting rapid genetic changes in B. canis that produced the emergence of alternative alleles at the VNTR loci [169]. Another example using MLVA is provided by Maquart et al. (2009) in marine Brucella: they cultured and typified bacteria from more than one tissue in 69 marine mammals, and they observed more than one genotype in sixteen of them. Moreover, $B$. suis 01-5744 recovered from four pigs, after 63 days of experimental infection, showed VNTR variation in three of 21 loci, as compared to the original strain [19].

Genomic comparison of isolates recovered during a specific period has also reported SNPs and length variation in B. suis and B. melitensis. For example, genomes of two B. suis clinical isolates from the same patient, eight years apart, showed a length difference of $2757 \mathrm{bp}$ [170]. Ke et al. (2012) performed an in vivo experiment where they looked for genomic changes in B. melitensis $16 \mathrm{M}$ recovered from infected mice at different times, simulating acute and chronic infections. This study reported 11 SNPs during the first week, and 5019 SNPs at the 13th week [171]. Even intergenic single SNPs can dramatically impact the phenotype of a bacterium $[140,141]$. The variation within the host reinforces the need for further research to confirm each SNP role, or the role of the some SNPs combination, on the Brucella phenotype, including attenuation. Indeed, looking at these variations requires high-quality metadata and high-resolution power techniques with high accuracy.

\section{Concluding Remarks}

Most of the emergent human pathogens have a zoonotic origin where transgression of host barriers is critical. Colonization of new environments requires behavioral adjustments in a bacterial population, which could lead to stable genetic modifications. In terms of understanding the emergence of pathogens, how bacteria living in soil can eventually adapt to milieus as different as an intracellular environment is an intriguing and relevant question.

Intracellular clonal bacteria that probably arose when their ancestor adapted to a particular host are confronted with the challenge of keeping genetic variability to respond to continuous stimuli originated by the host, especially, the immune system. With little chance of recombination or HGT, a bacterium with a medium-size genome, such as members of the Brucella genus, has limited sources for genetic plasticity.

The analysis of Brucella genomes from domestic and wildlife animals has expanded the knowledge of Brucella genetic variability. Lineages of divergence according to the geographic origin in B. cet $i$ and B. abortus become evident through the (i) specific IS711 insertion patterns across the genome, (ii) differential IS711 number, (iii) specific SNPs signatures across phylogenetic clusters, and (iv) pseudogenization of metabolic pathways. In contrast to the genomes of Brucella from marine mammals, the genomes of domestic animal bacteria have fewer SNPs and pseudogenes, suggesting a reduction of diversity in the latter bacteria as a consequence of domestication. Likewise, the diversity and divergence among the non-classical brucellae seem more extensive than the classical counterparts. This event is not an unexpected outcome, as the domestication process itself works as a selective pressure in the gene flow as a consequence of the co-evolution of pathogens and hosts [12,172]; this could have promoted and selected the close similarity observed in the B. abortus genomes isolated from cattle. Similar events likely occurred in the case of B. melitensis and B. suis with their respective hosts. We require more genomes of classical and non-classical organisms from wildlife animals for establishing comparisons. According to host specificities, other signatures of adaptation, including the fine-tune regulation of gene expression, are likely to occur in this intricate liaison. High-resolution studies of both bacterial population genetics, as well as studies of specific bacterial clusters displaying 
particular phenotypic traits, are necessary to unveil microevolution events that might be occurring. Despite the current knowledge, the central questions of brucellosis, regarding host adaptation and virulence variation require a solution. The fact that Brucella from wood rats, hares, and cold-blooded animals can infect humans $[78,114,173]$ depicts the zoonotic potential of all members of the genus and the ability of these bacteria to adapt from the preferred host to other animals and cause disease.

Supplementary Materials: Supplementary materials are at http://www.mdpi.com/1422-0067/21/20/7749/s1.

Author Contributions: Conceptualization: M.S.-E., E.C.-O., E.M., C.G.-V.; Investigation: M.S.-E., E.M., C.G.-V.; Writing original draft: M.S.-E.; Figures preparation: M.S.-E.; Writing-review and editing: M.S.-E., E.C.-O., E.M., C.G.-V.; Funding acquisition: E.C.-O., C.G.-V.; Project administration and supervision: C.G.-V. All authors have read and agreed to the published version of the manuscript.

Funding: This work was funded by Fondos del Sistema FEES/CONARE (0651), Fondos FIDA, Universidad Nacional (SIA 0047-17), Espacio Universitario de Estudios Avanzados, UCREA (B8762) from the presidency of University of Costa Rica, by the Vice Presidency for Research, University of Costa Rica (C0456) and Wellcome Trust Sanger Institute [098051].

Acknowledgments: We thank Nicholas R. Thomson at Parasites and Microbes from Pathogen Genomics, Wellcome Trust Sanger Institute for access to bioinformatics pipelines.

Conflicts of Interest: The authors declare no conflict of interest.

\section{Abbreviations}

$\begin{array}{ll}\text { CDS } & \text { Coding sequences } \\ \text { GIs } & \text { Genomic islands } \\ \text { IS } & \text { Insertion sequences } \\ \text { MGEs } & \text { Mobile genetic elements } \\ \text { MLST } & \text { Multi-locus sequence type } \\ \text { MLVA } & \text { Multiple loci variable number of tandem repeats } \\ \text { NAO } & \text { North Atlantic Ocean } \\ \text { PFGE } & \text { Pulse-field gel electrophoresis } \\ \text { SARs } & \text { shared anomalous region } \\ \text { SNPs } & \text { Single nucleotide polymorphisms } \\ \text { ST } & \text { Sequence type (ST) } \\ \text { TR } & \text { Tandem repeats } \\ \text { VNTR } & \text { Variable number of tandem repeats } \\ \text { WGS } & \text { Whole-genome sequencing }\end{array}$

\section{References}

1. Stackebrandt, E.; Murray, R.G.E.; Truper, H.G. Proteobacteria classis nov., a Name for the Phylogenetic Taxon That Includes the "Purple Bacteria and Their Relatives". Int. J. Syst. Bacteriol. 1988, 38, 321-325. [CrossRef]

2. Moreno, E. In search of a bacterial species definition. Rev. Biol. Trop. 1997, 45, 753-771.

3. Moreno, E. Genome evolution within the alpha Proteobacteria: Why do some bacteria not possess plasmids and others exhibit more than one different chromosome? Fems Microbiol. Rev. 1998, 22, 255-275. [CrossRef]

4. Ettema, T.J.G.; Andersson, S.G.E. The $\alpha$-proteobacteria: The Darwin finches of the bacterial world. Biol. Lett. 2009, 5, 429-432. [CrossRef]

5. Leclercq, S.; Cloeckaert, A.; Zygmunt, M. Taxonomic organization of the family Brucellaceae based on a phylogenomic approach. Front. Microbiol. 2019, 10, 3083. [CrossRef]

6. Michaux, S.; Paillisson, J.; Carles-Nurit, M.J.; Bourg, G.; Allardet-Servent, A.; Ramuz, M. Presence of two independent chromosomes in the Brucella melitensis 16M genome. J. Bacteriol. 1993, 175, 701-705. [CrossRef]

7. Jumas-Bilak, E.; Michaux-Charachon, S.; Bourg, G.; O'Callaghan, D.; Ramuz, M. Differences in chromosome number and genome rearrangements in the genus Brucella. Mol. Microbiol. 1998, 27, 99-106. [CrossRef]

8. Whatmore, A.M.; Perrett, L.L.; MacMillan, A.P. Characterisation of the genetic diversity of Brucella by multilocus sequencing. BMC Microbiol. 2007, 7, 34. [CrossRef] 
9. Bohlin, J.; Snipen, L.; Cloeckaert, A.; Lagesen, K.; Ussery, D.; Kristoffersen, A.B.; Godfroid, J. Genomic comparisons of Brucella spp. and closely related bacteria using base compositional and proteome based methods. Bmc Evol. Biol. 2010, 10, 249. [CrossRef]

10. Whatmore, A.M. Current understanding of the genetic diversity of Brucella, an expanding genus of zoonotic pathogens. Infect. Genet. Evol. 2009, 9, 1168-1184. [CrossRef]

11. Tsolis, R.M. Comparative genome analysis of the alpha -proteobacteria: Relationships between plant and animal pathogens and host specificity. Proc. Natl. Acad. Sci. USA 2002, 99, 12503-12505. [CrossRef]

12. Moreno, E. Retrospective and prospective perspectives on zoonotic brucellosis. Front. Microbiol. 2014, 5, 1-18. [CrossRef]

13. Atluri, V.L.; Xavier, M.N.; de Jong, M.F.; den Hartigh, A.B.; Tsolis, R.M. Interactions of the Human Pathogenic Brucella Species with Their Hosts. Annu. Rev. Microbiol. 2011, 65, 523-541. [CrossRef] [PubMed]

14. Williams, K.P.; Sobral, B.W.; Dickerman, A.W. A robust species tree for the Alphaproteobacteria. J. Bacteriol. 2007, 189, 4578-4586. [CrossRef] [PubMed]

15. Barquero-Calvo, E.; Conde-Alvarez, R.; Chacón-Díaz, C.; Quesada-Lobo, L.; Martirosyan, A.; Guzmán-Verri, C.; Iriarte, M.; Mancek-Keber, M.; Jerala, R.; Pierre, J.P.; et al. The Differential Interaction of Brucella and Ochrobactrum with Innate Immunity Reveals Traits Related to the Evolution of Stealthy Pathogens. PLoS ONE 2009, 4, e5893. [CrossRef]

16. Lebuhn, M.; Achouak, W.; Schloter, M.; Berge, O.; Meier, H.; Barakat, M.; Hartmann, A.; Heulin, T. Taxonomic characterization of Ochrobactrum sp. isolates from soil samples and wheat roots, and description of Ochrobactrum tritici sp. nov. and Ochrobactrum grignonense sp. nov. Int. J. Syst. Evol. Microbiol. 2000, 50, 2207-2223. [CrossRef]

17. Michaux-Charachon, S.; Bourg, G.; Jumas-Bilak, E.; Guigue-Talet, P.; Allardet-Servent, A.; O'Callaghan, D.; Ramuz, M. Genome structure and phylogeny in the genus Brucella. J. Bacteriol. 1997, 179, 3244-3249. [CrossRef]

18. Jensen, A.E.; Cheville, N.F.; Thoen, C.O.; MacMillan, A.P.; Miller, W.G. Genomic fingerprinting and development of a dendrogram for Brucella spp. isolated from seals, porpoises, and dolphins. J. Vet. Diagn. Investig. 1999, 11, 152-157. [CrossRef]

19. Whatmore, A.M.; Shankster, S.J.; Perrett, L.L.; Murphy, T.J.; Brew, S.D.; Thirlwall, R.E.; Cutler, S.J.; MacMillan, A.P. Identification and characterization of variable-number tandem-repeat markers for typing of Brucella spp. J. Clin. Microbiol. 2006, 44, 1982-1993. [CrossRef]

20. Le Flèche, P.; Jacques, I.; Grayon, M.; Al Dahouk, S.; Bouchon, P.; Denoeud, F.; Nöckler, K.; Neubauer, H.; Guilloteau, L.A.; Vergnaud, G. Evaluation and selection of tandem repeat loci for a Brucella MLVA typing assay. BMC Microbiol. 2006, 6, 9. [CrossRef] [PubMed]

21. Whatmore, A.M.; Koylass, M.S.; Muchowski, J.; Edwards-Smallbone, J.; Gopaul, K.K.; Perrett, L.L. Extended multilocus sequence analysis to describe the global population structure of the genus Brucella: Phylogeography and relationship to biovars. Front. Microbiol. 2016, 7, 1-14. [CrossRef] [PubMed]

22. Muñoz, P.M.; Mick, V.; Sacchini, L.; Janowicz, A.; de Miguel, M.J.; Cherfa, M.A.; Nevado, C.R.; Girault, G.; Andrés-Barranco, S.; Jay, M.; et al. Phylogeography and epidemiology of Brucella suis biovar 2 in wildlife and domestic swine. Vet. Microbiol. 2019, 233, 68-77. [CrossRef]

23. O'Callaghan, D.; Whatmore, A.M. Brucella genomics as we enter the multi-genome era. Brief. Funct. Genom. 2011, 10, 334-341. [CrossRef] [PubMed]

24. Ancora, M.; Marcacci, M.; Orsini, M.; Zilli, K.; Di Giannatale, E.; Garofolo, G.; Cammà, C. Complete Genome Sequence of a Brucella ceti ST26 Strain Isolated from a Striped Dolphin (Stenella coeruleoalba) on the Coast of Italy. Genome Announc. 2014, 2, 9-10. [CrossRef]

25. Duvnjak, S.; Špic, S.; Kušar, D.; Papic, B.; Reil, I.; Zdelar-Tuk, M.; Pavlinec, Z.; Duras, M.; Gomerčić, T.; Hendriksen, R.S.; et al. Whole-genome sequence of the first sequence type 27 brucella ceti strain isolated from european waters. Genome Announc. 2017, 5, 1-2. [CrossRef]

26. Garofolo, G.; Di Giannatale, E.; Platone, I.; Zilli, K.; Sacchini, L.; Abass, A.; Ancora, M.; Cammà, C.; Di Donato, G.; De Massis, F.; et al. Origins and global context of Brucella abortus in Italy. BMC Microbiol. 2017, 17, 1-7. [CrossRef] 
27. Suárez-Esquivel, M.; Baker, K.S.; Ruiz-Villalobos, N.; Hernández-Mora, G.; Barquero-Calvo, E.; González-Barrientos, R.; Castillo-Zeledón, A.; Jiménez-Rojas, C.; Chacón-Díaz, C.; Cloeckaert, A.; et al. Brucella genetic variability in wildlife marine mammals populations relates to host preference and ocean distribution. Genome Biol. Evol. 2017, 9, 1901-1912. [CrossRef] [PubMed]

28. Batut, J.; Andersson, S.G.E.; O'Callaghan, D. The evolution of chronic infection strategies in the alpha-proteobacteria. Nat. Rev. Microbiol. 2004, 2, 933-945. [CrossRef]

29. Nierman, W.C.; Feldblyum, T.V.; Laub, M.T.; Paulsen, I.T.; Nelson, K.E.; Eisen, J.; Heidelberg, J.F.; Alley, M.R.K.; Ohta, N.; Maddock, J.R.; et al. Complete genome sequence of Caulobacter crescentus. Proc. Natl. Acad. Sci. USA 2001, 98, 4136-4141. [CrossRef]

30. Kaneko, T.; Maita, H.; Hirakawa, H.; Uchiike, N.; Minamisawa, K.; Watanabe, A.; Sato, S. Complete genome sequence of the soybean symbiont Bradyrhizobium japonicum strain USDA6 T. Genes 2011, 2, 763-787. [CrossRef]

31. Paulsen, I.T.; Seshadri, R.; Nelson, K.E.; Eisen, J.A.; Heidelberg, J.F.; Read, T.D.; Dodson, R.J.; Umayam, L.; Brinkac, L.M.; Beanan, M.J.; et al. The Brucella suis genome reveals fundamental similarities between animal and plant pathogens and symbionts. Proc. Natl. Acad. Sci. USA 2002, 99, 13148-13153. [CrossRef] [PubMed]

32. Alsmark, C.M.; Frank, A.C.; Karlberg, E.O.; Legault, B.-A.; Ardell, D.H.; Cänback, B.; Eriksson, A.-S.; Näslund, A.K.; Handley, S.A.; Huvet, M.; et al. The louse-borne human pathogen Bartonella quintana is a genomic derivative of the zoonotic agent Bartonella henselae. Proc. Natl. Acad. Sci. USA 2004, 101, 9716-9721. [CrossRef]

33. Ogata, H.; Audic, S.; Renesto-Audiffren, P.; Fournier, P.-E.; Barbe, V.; Samson, D.; Roux, V.; Cossart, P.; Weissenbach, J.; Claverie, J.-M.; et al. Mechanisms of evolution in Rickettsia conorii and R. prowazekii. Scince 2001, 293, 2093-2098. [CrossRef] [PubMed]

34. Wu, M.; Sun, L.V.; Vamathevan, J.; Riegler, M.; Deboy, R.; Brownlie, J.C.; McGraw, E.A.; Martin, W.; Esser, C.; Ahmadinejad, N.; et al. Phylogenomics of the reproductive parasite Wolbachia pipientis wMel: A streamlined genome overrun by mobile genetic elements. PLoS Biol. 2004, 2, 327-341. [CrossRef] [PubMed]

35. Martínez-Cano, D.J.; Reyes-Prieto, M.; Martínez-Romero, E.; Partida-Martínez, L.P.; Latorre, A.; Moya, A.; Delaye, L. Evolution of small prokaryotic genomes. Front. Microbiol. 2015, 5, 742. [CrossRef] [PubMed]

36. Murray, G.G.R.; Charlesworth, J.; Miller, E.L.; Casey, M.J.; Lloyd, C.T.; Gottschalk, M.; Tucker, D.; Welch, J.J.; Weinert, L.A. Genome reduction is associated with bacterial pathogenicity across different scales of temporal and ecological divergence. bioRxiv 2020. [CrossRef]

37. Blanc, G.; Ogata, H.; Robert, C.; Audic, S.; Suhre, K.; Vestris, G.; Claverie, J.-M.; Raoult, D. Reductive genome evolution from the mother of Rickettsia. Plos Genet. 2007, 3, e14. [CrossRef]

38. Nakayama, K.; Yamashita, A.; Kurokawa, K.; Morimoto, T.; Ogawa, M.; Fukuhara, M.; Urakami, H.; Ohnishi, M.; Uchiyama, I.; Ogura, Y.; et al. The Whole-genome sequencing of the obligate intracellular bacterium Orientia tsutsugamushi revealed massive gene amplification during reductive genome evolution. Dna Res. 2008, 15, 85-99. [CrossRef]

39. Darby, A.C.; Cho, N.H.; Fuxelius, H.H.; Westberg, J.; Andersson, S.G. Intracellular pathogens go extreme: Genome evolution in the Rickettsiales. Trends Genet. 2007, 23, 511-520. [CrossRef]

40. Esser, C.; Martin, W.; Dagan, T. The origin of mitochondria in light of a fluid prokaryotic chromosome model. Biol. Lett. 2007, 3, 180-184. [CrossRef]

41. Sela, I.; Wolf, Y.I.; Koonin, E.V. Theory of prokaryotic genome evolution. Proc. Natl. Acad. Sci. USA 2016, 113, 11399-11407. [CrossRef] [PubMed]

42. Tsolis, R.M.; Seshadri, R.; Santos, R.L.; Sangari, F.J.; García Lobo, J.M.; de Jong, M.F.; Ren, Q.; Myers, G.; Brinkac, L.M.; Nelson, W.C.; et al. Genome degradation in Brucella ovis corresponds with narrowing of its host range and tissue tropism. PLoS ONE 2009, 4, e5519. [CrossRef] [PubMed]

43. Wattam, A.R.; Foster, J.T.; Mane, S.P.; Beckstrom-Sternberg, S.M.; Beckstrom-Sternberg, J.M.; Dickerman, A.W.; Keim, P.; Pearson, T.; Shukla, M.; Ward, D.V.; et al. Comparative phylogenomics and evolution of the brucellae reveal a path to virulence. J. Bacteriol. 2014, 196, 920-930. [CrossRef]

44. Eisenberg, T.; Riße, K.; Schauerte, N.; Geiger, C.; Blom, J.; Scholz, H. Isolation of a novel “atypical” Brucella strain from a bluespotted ribbontail ray (Taeniura lymma). Antonie Van Leeuwenhoek 2017, 110, 221-234. [CrossRef] [PubMed]

45. Dorsch, M.; Moreno, E.; Stackebrandt, E. Nucleotide sequence of the 16S rRNA from Brucella abortus. Nucleic Acids Res. 1989, 17, 1765. [CrossRef] 
46. Moreno, E.; Stackebrandt, E.; Dorsch, M.; Wolters, J.; Busch, M.; Mayer, H. Brucella abortus 16S rRNA and lipid A reveal a phylogenetic relationship with members of the alpha-2 subdivision of the class Proteobacteria. J. Bacteriol. 1990, 172, 3569-3576. [CrossRef]

47. Kettaneh, A.; Poilane, I.; Fain, O.; Thomas, M.; Herrmann, J.; Hocqueloux, L. Septic Shock Caused by Ochrobactrum anthropi in an Otherwise Healthy Host. J. Clin. Microbiol. 2003, 41, 1339-1341. [CrossRef]

48. Chain, P.S.G.; Lang, D.M.; Comerci, D.J.; Malfatti, S.A.; Vergez, L.M.; Shin, M.; Ugalde, R.A.; Garcia, E.; Tolmasky, M.E. Genome of Ochrobactrum anthropi ATCC 49188 T, a Versatile Opportunistic Pathogen and Symbiont of Several Eukaryotic Hosts. J. Bacteriol. 2011, 193, 4274-4275. [CrossRef]

49. Aujoulat, F.; Romano-Bertrand, S.; Masnou, A.; Marchandin, H.; Jumas-Bilak, E. Niches, population structure and genome reduction in Ochrobactrum intermedium: Clues to technology-driven emergence of pathogens. PLoS ONE 2014, 9, e83376. [CrossRef] [PubMed]

50. Jumas-Bilak, E.; Michaux-Charachon, S.; Bourg, G.; Ramuz, M.; Allardet-servent, A. Unconventional Genomic Organization in the Alpha Subgroup of the Proteobacteria. J. Bacteriol. 1998, 180, 2749-2755. [CrossRef]

51. Hammerl, J.A.; Göllner, C.; Al Dahouk, S.; Nöckler, K.; Reetz, J.; Hertwig, S. Analysis of the first temperate broad host range Brucellaphage (BiPBO1) isolated from B. inopinata. Front. Microbiol. 2016, 7, 1-13. [CrossRef] [PubMed]

52. Plommet, M. Prevention of Brucellosis in the Mediterranean countries; CIHEAM Publishers: Wageningen, The Netherlands, 1992; pp. 198-218.

53. Chain, P.S.G.; Comerci, D.J.; Tolmasky, M.E.; Larimer, F.W.; Malfatti, S.A.; Vergez, L.M.; Aguero, F.; Land, M.L.; Ugalde, R.A.; Garcia, E. Whole-genome analyses of speciation events in pathogenic brucellae. Infect. Immun. 2005, 73, 8353-8361. [CrossRef] [PubMed]

54. Mira, A.; Ochman, H.; Moran, N. Deletional bias and the evolution of bacterial genomes. Trends Genet. 2001, 17, 589-596. [CrossRef]

55. Lynch, M. Streamlining and simplification of microbial genome architecture. Annu Rev. Microbiol. 2006, 60, 327-349. [CrossRef]

56. Frank, A.C.; Alsmark, C.M.; Thollesson, M.; Andersson, S.G.E. Functional divergence and horizontal transfer of type IV secretion systems. Mol. Biol. Evol. 2005, 22, 1325-1336. [CrossRef]

57. Barquero-Calvo, E.; Chaves-Olarte, E.; Weiss, D.S.; Guzmán-Verri, C.; Chacón-Díaz, C.; Rucavado, A.; Moriyón, I.; Moreno, E. Brucella abortus uses a stealthy strategy to avoid activation of the innate immune system during the onset of infection. PLOS ONE 2007, 2. [CrossRef]

58. Moreno, E.; Cloeckaert, A.; Moriyón, I. Brucella evolution and taxonomy. Vet. Microbiol. 2002, 90, $209-227$. [CrossRef]

59. Rajashekara, G.; Glasner, J.D.; Glover, D.A.; Splitter, G.A. Comparative Whole-Genome Hybridization Reveals Genomic Islands in Brucella Species. J. Bacteriol. 2004, 186, 5040-5051. [CrossRef]

60. Mancilla, M. The Brucella genomic islands. In Brucella: Molecular Microbiology and Genomics; López-Goñi, I., O'Callaghan, D., Eds.; Caister Academic Press: Wymondham, UK, 2012; pp. 36-57. ISBN 978-1-904455-93-6.

61. Al Dahouk, S.; Köhler, S.; Occhialini, A.; Jiménez de Bagüés, M.P.; Hammerl, J.A.; Eisenberg, T.; Vergnaud, G.; Cloeckaert, A.; Zygmunt, M.S.; Whatmore, A.M.; et al. Brucella spp. of amphibians comprise genomically diverse motile strains competent for replication in macrophages and survival in mammalian hosts. Sci. Rep. 2017, 7, 44420. [CrossRef]

62. Soler-Lloréns, P.F.; Quance, C.R.; Lawhon, S.D.; Stuber, T.P.; Edwards, J.F.; Ficht, T.A.; Robbe-Austerman, S.; O'Callaghan, D.; Keriel, A. A Brucella spp. Isolate from a Pac-Man Frog (Ceratophrys ornata) Reveals Characteristics Departing from Classical Brucellae. Front. Cell. Infect. Microbiol. 2016, 6, 116. [CrossRef]

63. Eisenberg, T.; Hamann, H.-P.; Kaim, U.; Schlez, K.; Seeger, H.; Schauerte, N.; Melzer, F.; Tomaso, H.; Scholz, H.C.; Koylass, M.S.; et al. Isolation of potentially novel Brucella spp. from frogs. Appl. Env. Microbiol. 2012, 78, 3753-3755. [CrossRef]

64. Fischer, D.; Lorenz, N.; Heuser, W.; Kämpfer, P.; Scholz, H.; Lierz, M. Abscesses associated with a Brucella inopinata-like bacterium in a big-eyed tree frog (Leptopelis vermiculatus). J. Zoo Wildl. Med. 2012, 45, 625-628. [CrossRef]

65. Sobral, B.W.; Wattam, A.R. Comparative Genomics and Phuylogenomics of Brucella. In Brucella Molecular Microbiology and Genomics; Lopez-Goñi, I., O'Callaghan, D., Eds.; Caister Academic Press: Great, Britain, 2012; pp. 13-36. ISBN 978-1-904455-93-6. 
66. Eisenberg, T.; Schlez, K.; Fawzy, A.; Völker, I.; Hechinger, S.; Curić, M.; Schauerte, N.; Geiger, C.; Blom, J.; Scholz, H.C. Expanding the host range: Infection of a reptilian host (Furcifer pardalis) by an atypical Brucella strain. Antonie Van LeeuwenhoekInt. J. Gen. Mol. Microbiol. 2020, 113, 1531-1537. [CrossRef]

67. El-Sayed, A.; Awad, W. Brucellosis: Evolution and expected comeback. Int. J. Vet. Sci. Med. 2018, 6, S31-S35. [CrossRef]

68. Foster, J.T.; Beckstrom-Sternberg, S.M.; Pearson, T.; Beckstrom-Sternberg, J.S.; Chain, P.S.G.; Roberto, F.F.; Hnath, J.; Brettin, T.; Keim, P. Whole-genome-based phylogeny and divergence of the genus Brucella. J. Bacteriol. 2009, 191, 2864-2870. [CrossRef]

69. Moreno, E.; Moriyón, I. The Genus Brucella. In The Prokaryotes; Dworkin, M., Falkow, S., Rosenberg, E., Schleifer, K.-H., Stackebrandt, E., Eds.; Springer Link: Berlin/Heidelberg, Germany, 2006; pp. 315-456. ISBN 978-0-387-30745-9.

70. Nielsen, O.; Nielsen, K.; Stewart, R.E. Serologic evidence of Brucella spp. exposure in Atlantic walruses (Odobenus rosmarus rosmarus) and ringed seals (Phoca hispida) of Arctic Canada. Arctic 1996, 49, 383-386. [CrossRef]

71. Nymo, I.H.; Tryland, M.; Godfroid, J. A review of Brucella infection in marine mammals, with special emphasis on Brucella pinnipedialis in the hooded seal (Cystophora cristata). Vet. Res. 2011, 42, 93. [CrossRef]

72. Hernández-Mora, G.; Palacios-Alfaro, J.; González-Barrientos, R. Wildlife reservoirs of brucellosis: Brucella in aquatic environments and brucellosis serology. Rev. Sci. Tech. Off. Int. Epiz. 2013, 32, 89-103. [CrossRef]

73. McClelland, M.; Sanderson, K.E.; Clifton, S.W.; Latreille, P.; Porwollik, S.; Sabo, A.; Meyer, R.; Bieri, T.; Ozersky, P.; McLellan, M.; et al. Comparison of genome degradation in Paratyphi A and Typhi, human-restricted serovars of Salmonella enterica that cause typhoid. Nat. Genet. 2004, 36, 1268-1274. [CrossRef]

74. Thomson, N.R.; Clayton, D.J.; Windhorst, D.; Vernikos, G.; Davidson, S.; Churcher, C.; Quail, M.A.; Stevens, M.; Jones, M.A.; Watson, M.; et al. Comparative genome analysis of Salmonella Enteritidis PT4 and Salmonella Gallinarum 287/91 provides insights into evolutionary and host adaptation pathways. Genome Res. 2008, 18, 1624-1637. [CrossRef]

75. Holt, K.E.; Thomson, N.R.; Wain, J.; Langridge, G.C.; Hasan, R.; Bhutta, Z.A.; Quail, M.A.; Norbertczak, H.; Walker, D.; Simmonds, M.; et al. Pseudogene accumulation in the evolutionary histories of Salmonella enterica serovars Paratyphi A and Typhi. Bmc Genom. 2009, 10, 1-12. [CrossRef]

76. Kuijpers, L.M.F.; Le Hello, S.; Fawal, N.; Fabre, L.; Tourdjman, M.; Dufour, M.; Sar, D.; Kham, C.; Phe, T.; Vlieghe, E.; et al. Genomic analysis of Salmonella enterica serotype Paratyphi A during an outbreak in Cambodia, 2013-2015. Microb. Genom. 2016, 2, e000092. [CrossRef]

77. Guzmán-Verri, C.; Suárez-Esquivel, M.; Ruíz-Villalobos, N.; Michel, S.; Gonnet, M.; Campos, E.; Víquez-Ruiz, E.; Chacón-Díaz, C.; Conde-Alvarez, R.; Moriyón, I.; et al. Genetic and phenotypic characterization of the etiological agent of canine orchiepididymitis smooth Brucella sp. BCCN84.3. Front. Vet. Sci. 2019, 6, 175. [CrossRef]

78. Suárez-Esquivel, M.; Ruiz-Villalobos, N.; Jiménez-Rojas, C.; Barquero-Calvo, E.; Chacón-Díaz, C.; Víquez-Ruiz, E.; Rojas-Campos, N.; Baker, K.S.; Oviedo-Sánchez, G.; Amuy, E.; et al. Brucella neotomae Infection in Humans, Costa Rica. Emerg. Infect. Dis. J. 2017, 23, 997. [CrossRef]

79. Villalobos-Vindas, J.M.; Amuy, E.; Barquero-Calvo, E.; Rojas, N.; Chacón-Díaz, C.; Chaves-Olarte, E.; Guzman-Verri, C.; Moreno, E. Brucellosis caused by the wood rat pathogen Brucella neotomae: Two case reports. J. Med. Case Rep. 2017, 11, 1-4. [CrossRef]

80. Kang, Y.-S.; Brown, D.A.; Kirby, J.E. Brucella neotomae Recapitulates Attributes of Zoonotic Human Disease in a Murine Infection Model. Infect. Immun. 2018, 87, e00255-e18. [CrossRef]

81. Waldrop, S.G.; Sriranganathan, N. Intracellular invasion and survival of Brucella neotomae, another possible zoonotic Brucella species. PLoS ONE 2019, 14, 1-16. [CrossRef]

82. Sequeira, A.; Campos, E.; Mendoza, L.; San-Román, M.; Moreno, E. Identificación de especies y biotipos de Brucella aisladas en Costa Rica. Turrialba 1984, 34, 525-526.

83. Scholz, H.; Nöckler, K.; Göllner, C.; Bahn, P.; Cloeckaert, A.; Maquart, M.; Zygmunt, M.; Whatmore, A.; Pfeffer, M.; Huber, B.; et al. Brucella inopinata sp. nov., isolated from a breast implant infection. Int. J. Syst. Evol. Microbiol. 2010, 60, 801-808. [CrossRef] 
84. Suárez-Esquivel, M.; Ruiz-Villalobos, N.; Hernández-Mora, G.; González-Barrientos, R.; Palacios-Alfaro, J.D.; Barquero-Calvo, E.; Chaves-Olarte, E.; Thomson, N.; Moreno, E.; Guzmán Verri, C. Brucella Sequence Type 27 Isolated from Dwarf Sperm Whale (Kogia sima) stranded in the Costa Rican Pacifi Coast. Access Microbioly 2019, 1, 911.

85. Whatmore, A.M.; Dawson, C.E.; Groussaud, P.; Koylass, M.S.; King, A.C.; Shankster, S.J.; Sohn, A.H.; Probert, W.S.; McDonald, W.L. Marine mammal Brucella genotype associated with zoonotic infection. Emerg. Infect. Dis. 2008, 14, 517-518. [CrossRef]

86. Cook, I.; Campbell, R.; Barrow, G. Brucellosis in North Queensland rodents. Aust. Vet. J. 1966, 42, 5-8. [CrossRef] [PubMed]

87. Davis, D. Brucellosis in wildlife. In Animal brucellosis; Nielsen, K., Duncan, J., Eds.; CRC Press: Boca Raton, FL, USA, 1990; pp. 321-334.

88. Tiller, R.V.; Gee, J.E.; Frace, M.A.; Taylor, T.K.; Setubal, J.C.; Hoffmaster, A.R.; De, B.K. Characterization of novel Brucella strains originating from wild native rodent species in North Queensland, Australia. Appl. Env. Microbiol. 2010, 76, 5837-5845. [CrossRef]

89. Hume, D.A.; Whitelaw, C.B.A.; Archibald, A.L. The future of animal production: Improving productivity and sustainability. J. Agric. Sci. 2011, 149, 9-16. [CrossRef]

90. Glass, E.J. The molecular pathways underlying host resistance and tolerance to pathogens. Front. Genet. 2012, 3, 1-12. [CrossRef] [PubMed]

91. Larson, G.; Fuller, D.Q. The Evolution of Animal Domestication. Annu. Rev. Ecol. Evol. Syst. 2014, 45, 115-136. [CrossRef]

92. Marshall, F.B.; Dobney, K.; Denham, T.; Capriles, J.M. Evaluating the roles of directed breeding and gene flow in animal domestication. Proc. Natl. Acad. Sci. USA 2014, 111, 6153-6158. [CrossRef]

93. Read, A.; Baigent, S.; Powers, C.; Kgosana, L.; Blackwell, L.; Al, E. Imperfect Vaccination Can Enhance the Transmission of Highly Virulent Pathogens. PLoS Biol. 2015, 13, e1002198. [CrossRef] [PubMed]

94. Turcotte, M.M.; Araki, H.; Karp, D.S.; Poveda, K.; Whitehead, S.R. The eco-evolutionary impacts of domestication and agricultural practices on wild species. Philos. Trans. R. Soc. B Biol. Sci. 2017, 372, 20160033. [CrossRef] [PubMed]

95. Weinert, L.A.; Welch, J.J.; Suchard, M.A.; Lemey, P.; Rambaut, A.; Fitzgerald, J.R. Molecular dating of human-to-bovid host jumps by Staphylococcus aureus reveals an association with the spread of domestication. Biol. Lett. 2012, 8, 829-832. [CrossRef] [PubMed]

96. Wattam, A.R.; Williams, K.P.; Snyder, E.E.; Almeida, N.F.; Shukla, M.; Dickerman, A.W.; Crasta, O.R.; Kenyon, R.; Lu, J.; Shallom, J.M.; et al. Analysis of ten Brucella genomes reveals evidence for horizontal gene transfer despite a preferred intracellular lifestyle. J. Bacteriol. 2009, 191, 3569-3579. [CrossRef]

97. Foster, J.T.; Price, L.B.; Beckstrom-Sternberg, S.M.; Pearson, T.; Brown, W.D.; Kiesling, D.M.; Allen, C.A.; Liu, C.M.; Beckstrom-Sternberg, J.; Roberto, F.F.; et al. Genotyping of Brucella species using clade specific SNPs. BMC Microbiol. 2012, 12, 110. [CrossRef]

98. Vergnaud, G.; Hauck, Y.; Christiany, D.; Daoud, B.; Pourcel, C.; Jacques, I.; Cloeckaert, A.; Zygmunt, M.S. Genotypic expansion within the population structure of classical Brucella species revealed by MLVA16 typing of 1404 Brucella isolates from different animal and geographic origins, 1974-2006. Front. Microbiol. 2018, 9,1-11. [CrossRef]

99. Groussaud, P.; Shankster, S.J.; Koylass, M.S.; Whatmore, A.M. Molecular typing divides marine mammal strains of Brucella into at least three groups with distinct host preferences. J. Med. Microbiol. 2007, 56, 1512-1518. [CrossRef] [PubMed]

100. Maquart, M.; Le Flèche, P.; Foster, G.; Tryland, M.; Ramisse, F.; Djønne, B.; Al Dahouk, S.; Jacques, I.; Neubauer, H.; Walravens, K.; et al. MLVA-16 typing of 295 marine mammal Brucella isolates from different animal and geographic origins identifies 7 major groups within Brucella ceti and Brucella pinnipedialis. BMC Microbiol. 2009, 9, 145. [CrossRef] [PubMed]

101. Isidoro-Ayza, M.; Ruiz-Villalobos, N.; Pérez, L.; Guzmán-Verri, C.; Muñoz, P.M.; Alegre, F.; Barberán, M.; Chacón-Díaz, C.; Chaves-Olarte, E.; González-Barrientos, R.; et al. Brucella ceti infection in dolphins from the Western Mediterranean sea. Bmc Vet. Res. 2014, 10, 206. [CrossRef] [PubMed]

102. Dawson, C.E.; Perrett, L.L.; Young, E.J.; Davison, N.J.; Monies, R.J. Isolation of Brucella species from a bottlenosed dolphin (Tursiops truncatus). Vet. Rec. 2006, 158, 831-832. [CrossRef] [PubMed] 
103. Sheppard, S.K.; Guttman, D.S.; Fitzegerald, J.R. Population genomics of bacterial host adaptation. Nat. Rev. Genet. 2018, 19, 1. [CrossRef]

104. Godfroid, J.; Cloeckert, A.; Liautard, J.P.; Kohler, S.; Fretin, D.; Walravens, K.; Garin-Bastuji, B.; Letesson, J.-J. From the discovery of the Malta fever's agent to the discovery of a marine mammal reservoir, brucellosis has continuously been a re-emerging zoonosis. Vet. Res. 2005, 36, 313-326. [CrossRef]

105. Godfroid, J.; Garin-Bastuji, B.; Saegerman, C.; Blasco, J.M. Brucellosis in terrestrial wildlife. Rev. Sci. Technol. 2013, 32, 27-42. [CrossRef]

106. Lord, V.R.; Cherwonogrodzky, J.W.; Marcano, M.J.; Melendez, G. Serological and bacteriological study of swine brucellosis. J. Clin. Microbiol. 1997, 35, 295-297. [CrossRef] [PubMed]

107. Poester, F.P.; Gonçalves, V.S.P.; Lage, A.P. Brucellosis in Brazil. Vet. Microbiol. 2002, 90, 55-62. [CrossRef]

108. Cvetnić, Z.; Špičić, S.; Tončić, J.; Majnarić, D.; Benić, M.; Albert, D.; Thiébaud, M.; Garin-Bastuji, B. Brucella suis infection in domestic pigs and wild boar in Croatia. Rev. Sci. Tech. Off. Int. Epiz. 2009, 28, 1057-1067. [CrossRef]

109. Becker, H.N.; Belden, R.C.; Breault, T.; Burridge, M.J.; Frankenberger, W.; Nicoletti, P. Brucellosis in feral swine in Florida. J. Am.Vet. Med. Assoc. 1978, 173, 1181-1182. [PubMed]

110. Cornell, W.D.; Chengappa, M.M.; Stuart, L.A.; Maddux, R.L.; Hail, R.I. Brucella suis biovar 3 infection in a Kentucky swine herd. J. Vet. Diagn. Investig. 1989, 1, 20-21. [CrossRef]

111. Robson, J.M.; Harrison, M.W.; Wood, R.N.; Tilse, M.H.; McKay, A.B.; Brodribb, T.R. Brucellosis: Re- emergence and changing epidemiology in Queensland. Med. J. Aust. 1993, 159, 153-158. [CrossRef] [PubMed]

112. Deqiu, S.; Donglou, X.; Jiming, Y. Epidemiology and control of brucellosis in China. Vet. Microbiol. 2002, 90, 165-182. [CrossRef]

113. Ferreira, A.C.; Tenreiro, R.; da Sá, M.I.C.; Dias, R. Evolution and genome specialization of Brucella suis biovar 2 Iberian lineages. BMC Genom. 2017, 18, 1-12. [CrossRef]

114. Mailles, A.; Ogielska, M.; Kemiche, F.; Garin-Bastuji, B.; Al, E. Brucella suis biovar 2 infection in humans in France: Emerging infection or better recognition? Epidemiol. Infect. 2017, 145, 2711-2716. [CrossRef]

115. Forbes, L.B. Isolates of Brucella suis biovar 4 from animals and humans in Canada, 1982-1990. Can. Vet. J. 1991, 32, 686-688.

116. Olsen, S.; Tatum, F. Swine brucellosis: Current perspectives. Vet. Med. Res. Rep. 2016, 8, 1-12. [CrossRef]

117. Suárez-Esquivel, M.; Hernández-Mora, G.; Ruiz-Villalobos, N.; Barquero-Calvo, E.; Rojas-Campos, N.; Ladner, J.; Oviedo-Sánchez, G.; Chacón-Díaz, C.; Chaves-Olarte, E.; Foster, J.T.; et al. Persistence of Brucella abortus lineages revealed by genomic characterization and phylodynamic analysis. PLoS Negl. Trop. Dis. 2020, 14, e0008235.

118. Dorneles, E.M.S.; Santana, J.A.; Alves, T.M.; Pauletti, R.B.; Mol, J.P.D.S.; Heinemann, M.B.; Lage, A.P. Genetic stability of Brucella abortus isolates from an outbreak by multiple-locus variable-number tandem repeat analysis (MLVA16). BMC Microbiol. 2014, 14, 1-8. [CrossRef] [PubMed]

119. Hernández-Mora, G.; Ruiz-Villalobos, N.; Bonilla-Montoya, R.; Romero-Zúniga, J.J.; Jiménez-Arias, J.; González-Barrientos, R.; Barquero-Calvo, E.; Chacón-Díaz, C.; Rojas, N.; Chaves-Olarte, E.; et al. Epidemiology of bovine brucellosis in Costa Rica: Lessons learned from failures in the control of the disease. PLoS ONE 2017, 12, 1-17. [CrossRef] [PubMed]

120. Alvarez, L.P.; Ruiz-Villalobos, N.; Suárez-Esquivel, M.; Thomson, N.R.; Marcellino, R.; Víquez-Ruiz, E.; Robles, C.A.; Guzmán-Verri, C. Molecular characterization of Brucella ovis in Argentina. Vet. Microbiol. 2020, 245, 108703. [CrossRef]

121. Lan, R.; Reeves, P.R. Intraspecies variation in bacterial genomes: The need for a species genome concept. Trends Microbiol. 2000, 8, 396-401. [CrossRef]

122. Wion, D.; Casadesús, J. N6-methyl-adenine: An epigenetic signal for DNA-protein interactions. Nat. Rev. Microbiol. 2006, 4, 183-192. [CrossRef]

123. Robertson, G.; Reisenauer, A.; Wright, R.; Jensen, R.; Jensen, A.; Shapiro, L.; Roop II, R.M. The Brucella abortus CcrM DNA Methyltransferase Is Essential for Viability, and Its Overexpression Attenuates Intracellular Replication in Murine Macrophages. J. Bacteriol. 2000, 182, 3482-3489. [CrossRef]

124. Zhou, K.; Aertsen, A.; Michiels, C.W. The role of variable DNA tandem repeats in bacterial adaptation. Fems Microbiol. Rev. 2014, 38, 119-141. [CrossRef]

125. Press, M.O.; Queitsch, C. Variability in a short tandem repeat mediates complex epistatic interactions in Arabidopsis thaliana. Genetics 2017, 205, 455-464. [CrossRef] 
126. Gerner-Smidt, P.; Hyytiä-Trees, E.; Rota, P.A. Molecular Epidemiology. In Manual of Clinical Microbiology; Versalovic, J., Carroll, K.C., Funke, G., Jorgensen, J.H., Landry, M.L., Warnock, D.M., Eds.; ASM Press: Washington, DC, USA, 2011; pp. 100-123.

127. Deka, R.; Shriver, M.D.; Yu, L.; Ferrell, R.; Chakraborty, R. Intra- and inter-population diversity at short tandem repeat loci in diverse populations of the world. Electrophoresis 1995, 16, 1659-1664. [CrossRef] [PubMed]

128. Bricker, B.J.; Ewalt, D.R.; Halling, S.M. Brucella "HOOF-Prints": Strain typing by multi-locus analysis of variable number tandem repeats (VNTRs). BMC Microbiol. 2003, 13, 15.

129. Higgins, J.; Stuber, T.; Quance, C.; Edwards, W.H.; Tiller, R.V.; Linfield, T.; Rhyan, J.; Berte, A.; Harris, B. Molecular epidemiology of Brucella abortus isolates from Cattle, Elk, and Bison in the United States, 1998 to 2011. Appl. Env. Microbiol. 2012, 78, 3674-3684. [CrossRef] [PubMed]

130. Allen, A.; Breadon, E.; Byrne, A.; Mallon, T.; Skuce, R.; Groussaud, P.; Dainty, A.; Graham, J.; Jones, K.; Pollock, L.; et al. Molecular epidemiology of Brucella abortus in Northern Ireland-1991 to 2012. PLoS ONE 2015, 10, 1-23. [CrossRef]

131. Shevtsov, A.; Ramanculov, E.; Shevtsova, E.; Kairzhanova, A.; Tarlykov, P.; Filipenko, M.; Dymova, M.; Abisheva, G.; Jailbekova, A.; Kamalova, D.; et al. Genetic diversity of Brucella abortus and Brucella melitensis in Kazakhstan using MLVA-16. Infect. Genet. Evol. 2015, 34, 173-180. [CrossRef]

132. Hernández-Mora, G.; Bonilla-Montoya, R.; Barrantes-Granados, O.; Esquivel-Suárez, A.; Montero-Caballero, D.; González-Barrientos, R.; Fallas-Monge, Z.; Palacios-Alfaro, J.D.; Baldi, M.; Campos, E.; et al. Brucellosis in mammals of Costa Rica: An epidemiological survey. PLoS ONE 2017, 12, e0182644. [CrossRef]

133. Al Dahouk, S.; Le Flèche, P.; Nockler, K.; Jacques, I.; Grayon, M.; Scholz, H.C.; Tomaso, H.; Vergnaud, G.; Neubauer, H. Evaluation of Brucella MLVA typing for human brucellosis. J. Microbiol. Methods 2007, 69, 137-145. [CrossRef]

134. Foster, J.T.; Walker, F.M.; Rannals, B.D.; Hammad Hussain, M.; Drees, K.P.; Tiller, R.V.; Hoffmaster, A.R.; Al-Rawahi, A.; Keim, P.; Saqib, M. African lineage Brucella melitensis Isolates from Omani livestock. Front. Microbiol. 2018, 8, 2702. [CrossRef] [PubMed]

135. Georgi, E.; Walter, M.C.; Pfalzgraf, M.T.; Northoff, B.H.; Holdt, L.M.; Scholz, H.C.; Zoeller, L.; Zange, S.; Antwerpen, M.H. Whole genome sequencing of Brucella melitensis isolated from 57 patients in Germany reveals high diversity in strains from Middle East. PLoS ONE 2017, 12, 1-15. [CrossRef]

136. Janowicz, A.; De Massis, F.; Ancora, M.; Cammà, C.; Patavino, C.; Battisti, A.; Prior, K.; Harmsen, D.; Scholz, H.; Zilli, K.; et al. Core Genome Multilocus Sequence Typing and Single Nucleotide Polymorphism Analysis in the Epidemiology of Brucella melitensis Infections. J. Clin. Microbiol. 2018, 56, e00517-e00518. [CrossRef]

137. Brito, P.H.; Edwards, S.V. Multilocus phylogeography and phylogenetics using sequence-based markers. Genetica 2009, 135, 439-455. [CrossRef] [PubMed]

138. Halling, S.M.; Peterson-burch, B.D.; Betsy, J.; Zuerner, R.L.; Qing, Z.; Li, L.; Alt, D.P.; Olsen, S.C.; Bricker, B.J.; Kapur, V. Completion of the Genome Sequence of Brucella abortus and Comparison to the Highly Similar Genomes of Brucella melitensis and Brucella suis. J. Bacteriol. 2005, 187, 2715-2726. [CrossRef] [PubMed]

139. Borriello, G.; Russo, V.; Paradiso, R.; Riccardi, M.G.; Criscuolo, D.; Verde, G.; Marasco, R.; Pedone, P.V.; Galiero, G.; Baglivo, I. Different impacts of mucr binding to the babr and virb promoters on gene expression in Brucella abortus 2308. Biomolecules 2020, 10, 788. [CrossRef]

140. Viana, D.; Comos, M.; Mcadam, P.R.; Ward, M.J.; Selva, L.; Guinane, M.; González-muñoz, B.M.; Tristan, A.; Foster, S.J.; Ross, J. A single natural nucleotide mutation alters bacterial pathogen host-tropism. Nat. Genet. 2015, 47, 361-366. [CrossRef]

141. Hammarlöf, D.L.; Kröger, C.; Owen, S.V.; Canals, R.; Lacharme-Lora, L.; Wenner, N.; Schager, A.E.; Wells, T.J.; Henderson, I.R.; Wigley, P.; et al. Role of a single noncoding nucleotide in the evolution of an epidemic African clade of Salmonella. Proc. Natl. Acad. Sci. USA 2018, 115, E2614-E2623. [CrossRef] [PubMed]

142. Holzapfel, M.; Girault, G.; Keriel, A.; Ponsart, C.; O'Callaghan, D.; Mick, V. Comparative genomics and in vitro infection of field clonal isolates of Brucella melitensis biovar 3 did not identify signature of host Adaptation. Front. Microbiol. 2018, 9, 1-6. [CrossRef] 
143. Maiden, M.C.J.; Jansen Van Rensburg, M.J.; Bray, J.E.; Earle, S.G.; Ford, S.A.; Jolley, K.A.; McCarthy, N.D. MLST revisited: The gene-by-gene approach to bacterial genomics. Nat. Rev. Microbiol. 2013, 11, 728-736. [CrossRef]

144. Maiden, M.C.J.; Bygraves, J.A.; Feil, E.; Morelli, G.; Russell, J.E.; Urwin, R.; Zhang, Q.; Zhou, J.; Zurth, K.; Caugant, D.A.; et al. Multilocus sequence typing: A portable approach to the identification of clones within populations of pathogenic microorganisms. Proc. Natl. Acad. Sci. USA 1998, 95, 3140-3145. [CrossRef]

145. Goodhead, I.; Darby, A.C. Taking the pseudo out of pseudogenes. Curr. Opin. Microbiol. 2015, 23, $102-109$. [CrossRef]

146. Dagan, T.; Blekhman, R.; Graur, D. The "domino theory" of gene death: Gradual and mass gene extinction events in three lineages of obligate symbiotic bacterial pathogens. Mol. Biol. Evol. 2006, 23, 310-316. [CrossRef]

147. Sasidharan, R.; Gerstein, M. Genomics: Protein fossils live on as RNA. Nature 2008, 453, 729-731. [CrossRef]

148. Tutar, Y. Pseudogenes. Comp. Funct. Genom. 2012, 2012, 424526. [CrossRef] [PubMed]

149. Moreno, E.; Mayer, H.; Moriyon, I. Characterization of a native polysaccharide hapten from Brucella melitensis. Infect. Immun. 1987, 55, 2850-2853. [CrossRef] [PubMed]

150. Scholz, H.C.; Mu, K.; Shilton, C.; Benedict, S. The Change of a Medically Important Genus: Worldwide Occurrence of Genetically Diverse Novel Brucella Species in Exotic Frogs. PLoS ONE 2016, 11, e0168872. [CrossRef]

151. Siguier, P.; Gourbeyre, E.; Chandler, M. Bacterial insertion sequences: Their genomic impact and diversity. Fems Microbiol. Rev. 2014, 38, 865-891. [CrossRef] [PubMed]

152. Vandecraen, J.; Chandler, M.; Aertsen, A.; Houdt, R. Van. The impact of insertion sequences on bacterial genome plasticity and adaptability. Crit. Rev. Microbiol. 2017, 43, 709-730. [CrossRef]

153. Halling, S.M.; Tatum, F.M.; Bricker, B.J. Sequence and characterization of an insertion sequence, IS711 from Brucella ovis. Gene 1993, 133, 123-127. [CrossRef]

154. Halling, S.M.; Zuerner, R.L. Evidence for lateral transfer to Brucellae: Characterization of a locus with a Tn-like element (Tn2020). Biochim. Biophys. Acta Gene Struct. Expr. 2002, 1574, 109-116. [CrossRef]

155. Sriranganathan, N.; Seleem, M.N.; Olsen, S.C.; Samartino, L.E.; Whatmore, A.M.; Bricker, B.; O'Callaghan, D.; Halling, S.M.; Crasta, O.R.; Wattam, R.A.; et al. Brucella. In Genome Mapping and Genomics in Animal-Associated Microbes; Nene, V., Kole, C., Eds.; Springer: Heidelberg, Germany, 2009; pp. 15-16. ISBN 978-3-540-74040-7.

156. Ocampo-Sosa, A.A.; García-Lobo, J.M. Demonstration of IS711 transposition in Brucella ovis and Brucella pinnipedialis. BMC Microbiol. 2008, 8, 1-10. [CrossRef]

157. Bounaadja, L.; Albert, D.; Chénais, B.; Hénault, S.; Zygmunt, M.S.; Poliak, S.; Garin-Bastuji, B. Real-time PCR for identification of Brucella spp.: A comparative study of IS711, bcsp31 and per target genes. Vet. Microbiol. 2009, 137, 156-164. [CrossRef]

158. Bricker, B.J. PCR as a diagnostic tool for brucellosis. Vet. Microbiol. 2002, 90, 435-446. [CrossRef]

159. Cloeckaert, A.; Bernardet, N.; Koylass, M.S.; Whatmore, A.M.; Zygmunt, M.S. Novel IS711 chromosomal location useful for identification of marine mammal Brucella genotype ST27, which is associated with zoonotic infection. J. Clin. Microbiol. 2011, 49, 3954-3959. [CrossRef]

160. Mancilla, M.; Ulloa, M.; Lápez-Gõi, I.; Moriyán, I.; María Zárraga, A. Identification of new IS711 insertion sites in Brucella abortus field isolates. BMC Microbiol. 2011, 11, 176. [CrossRef] [PubMed]

161. Bricker, B.J.; Ewalt, D.R.; MacMillan, A.P.; Foster, G.; Brew, S. Molecular characterization of Brucella strains isolated from marine mammals. J. Clin. Microbiol. 2000, 38, 1258-1262. [CrossRef]

162. Zygmunt, M.S.; Maquart, M.; Bernardet, N.; Doublet, B.; Cloeckaert, A. Novel IS711-specific chromosomal locations useful for identification and classification of marine mammal Brucella strains. J. Clin. Microbiol. 2010, 48, 3765-3769. [CrossRef] [PubMed]

163. Suárez-Esquivel, M.; Ruiz-Villalobos, N.; Castillo-Zeledón, A.; Jiménez-Rojas, C.; Roop II, R.M.; Comerci, D.J.; Barquero-Calvo, E.; Chacón-Díaz, C.; Caswell, C.C.; Baker, K.S.; et al. Brucella abortus Strain 2308 Wisconsin Genome: Importance of the Definition of Reference Strains. Front. Microbiol. 2016, 7, 1-6. [CrossRef] [PubMed]

164. Łoś, M.; Węgrzyn, G. Pseudolysogeny. Adv. Virus Res. 2012, 82, 339-349.

165. Hacker, J.; Kaper, J.B. Pathogenicity Islands and the Evolution of Microbes. Annu. Rev. Microbiol. 2008, 54, 641-679. [CrossRef] 
166. Vernikos, G.S.; Parkhill, J. Resolving the structural features of genomic islands: A machine learning approach. Genome Res. 2008, 18, 331-342. [CrossRef]

167. Darmon, E.; Leach, D.R.F. Bacterial Genome Instability. Microbiol. Mol. Biol. Rev. 2014, 78, 1-39. [CrossRef]

168. Pérez-Lago, L.; Comas, I.; Navarro, Y.; González-Candelas, F.; Herranz, M.; Bouza, E.; García-De-Viedma, D. Whole Genome Sequencing Analysis of Intrapatient Microevolution in Mycobacterium tuberculosis: Potential Impact on the Inference of Tuberculosis Transmission. J. Infect. Dis. 2014, 209, 98-108. [CrossRef] [PubMed]

169. Gyuranecz, M.; Rannals, B.D.; Allen, C.A.; Jánosi, S.; Keim, P.S.; Foster, J.T. Within-host evolution of Brucella canis during a canine brucellosis outbreak in a kennel. BMC Vet. Res. 2013, 9, 76. [CrossRef]

170. Viana, M.V.C.; Wattam, A.R.; Govil Batra, D.; Boisvert, S.; Brettin, T.S.; Frace, M.; Xia, F.; Azevedo, V.; Tiller, R.; Hoffmaster, A.R. Genome Sequences of Two Brucella suis Strains Isolated from the Same Patient, 8 Years Apart. Genome Announc. 2017, 5, e01687-e16. [CrossRef]

171. Ke, Y.; Yuan, X.; Wang, Y.; Bai, Y.; Xu, J.; Song, H.; Huang, L.; Chen, Z. Genome sequences of Brucella melitensis $16 \mathrm{M}$ and its two derivatives 16M1w and 16M13w, which evolved in vivo. J. Bacteriol. 2012, 194, 5489. [CrossRef]

172. Ewald, P.W. Evolution of virulence. Infect. Dis. Clin. N. Am. 2004, 18, 1-15. [CrossRef]

173. Rouzic, N.; Desmier, L.; Cariou, M.; Gay, E.; Foster, J.; Williamson, C.; Schmitt, F.; Le Henaff, M.; Le Coz, A.; Lorléac'h, A.; et al. First case of brucellosis caused by an amphibian-type Brucella. Clin Infect. Dis 2020. [CrossRef] [PubMed]

Publisher's Note: MDPI stays neutral with regard to jurisdictional claims in published maps and institutional affiliations.

(C) 2020 by the authors. Licensee MDPI, Basel, Switzerland. This article is an open access article distributed under the terms and conditions of the Creative Commons Attribution (CC BY) license (http://creativecommons.org/licenses/by/4.0/). 